\title{
On the Legitimacy of Cross-Border Pharmacy
}

\author{
SIMON R. RABINOVITCH
}

Cross-border pharmacy sales of prescription drugs to U.S. patients by Canadian Internet pharmacies have generased significant controversy in the U.S. and Canada. Violative of U.S. legislation and Canadian professional codes of conduct, cross-border pharmacy has nonetheless flourished in response to strong demand and incomplete enforcement. Proponents laud the greater affordability of needed drugs provided by cross-border pharmacy: opponents decry the practice as unsafe, economically ill-advised and harmful to Canadian inserests in the long term.

This article evaluates the safety arguments that have been put fonvard by the U.S. Food and Drug Administration and others and concludes that they do not justify a prohibition on prescription drug imports from Canada. Similarly. Canadian professional regulasory bodies 'objections to the participation of Canadian pharmacists and physicians in cross-border dispensing are a misapplication of conduct rules developed in another context. Objections to crossborder drug sales based on an economic analysis assume normative positions that should be explicitly identified and socially determined. On the other hand. if patient safen: professional responsibiliny and economic arguments fail to provide adequate support for a policy of prohibition, then self-interest in protecting domestic drug supplies and prices may support, at least from a Canadian perspective. some constraints on cross-border pharmacy.
Les ventes transfrontalières par Internet de médicaments d'ordonnance à des palients américains auprès de pharmacies canadiennes ons engendre beaucoup de controverse aux Élats-Unis et au Canada. Contrevenant d la loi américaine et aux codes de conduite professionnelle canadiens. les pharmacies transfrontalieres ont néanmoins pris un essor suite dane forte demande et une application incomplète des lois. Ceux qui sont pour sont heureux de la plus grande disponibilité de médicaments et ceux qui sont contre decrivent la pratique comme dtant dangereuse, dconomiquement malvenue ef mauvaise pour les intérèts canadiens à long terme. Cet article examine les arguments de sécurité qui ont tite présentess a la Food and Drug Administration et autres organismes, et conciuent que ces argumenis ne justifient pas l'interdiction de l'importation de médicaments d'ordonnance du Canada. Pareillement. les objections des organismes de réglementation professionnelle du Canada. à l'égard de la participation des pharmaciens et médecins canadiens à celle pratique, représemtemt une application erronée des règles de déontologie développées dans un autre comlexte. Les objections à lëgard de la vente sransfrontaliere de midicaments, fondèes sur une analyse économique, supposent que des positions normatives doivent ètre explicitement identifiées et déterminées de manière sociale. Par ailleurs. si la sécurité du patient, la responsabilité professionnelle et les arguments économiques ne suffisent pas à interdire la pratique. alors l'intérét personnel à protéger les provisions nationales de médicaments et les prix peuvent, du moins à partir d'un point de vue canadien, aider à limiter la pratique des pharmacies iransfrontalières.

\section{Table of CONTENTS}

I. INTRODUCTION ............................. 328

II. THE MECHANICS AND CONTEXT OF

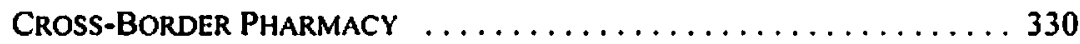

A. Drug Prices Vary Internationally $\ldots \ldots \ldots \ldots \ldots \ldots .330$

B. Why are Patented Drug Prices lower

IN CANADA THAN IN THE UNITED STATES?

This article builds on work presented at the CIHR Training Program Health Law and Policy colloquium in Halifax, N.S., 6-7 May 2004. I would like to thank the CIHR for sponsoring the colloquium and Colleen Flood, Tim Caulfield and Jocelyn Downie for providing constructive feedback. 

C. THE LOGISTICS OF A CROSS-BORDER
Pharmacy Transaction . . . . . . . . . . . . . . . . . 333
D. Canadian Cross-Border Pharmacies $\ldots \ldots \ldots \ldots \ldots \ldots . \ldots \ldots 34$
E. WHO ARE THE CROSS-BORDER
Pharmacy Customers? . . . . . . . . . . . . . . . . 335

III. AMERICAN REGULATION OF CROSS-Border PHARMACY $\ldots \ldots \ldots \ldots 337$

A. Federal legislation $\ldots \ldots \ldots \ldots \ldots \ldots \ldots \ldots \ldots \ldots \ldots \ldots \ldots \ldots \ldots$

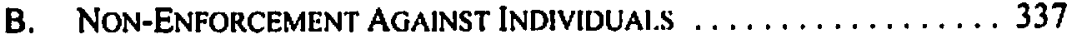

C. FOOD AND DRUG ADMINISTRATION ENFORCEMENT

AGAINST AMERICAN STOREFRONT OPERATIONS $\ldots \ldots \ldots \ldots \ldots .338$

D. THE FOOD AND DRUG ADMINISTRATION

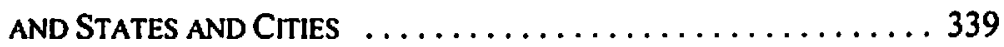

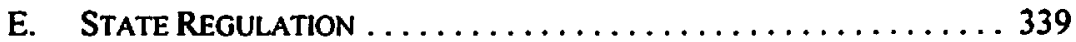

IV. AMERICAN PRESCRIPTION DRUG IMPORT LEGISLATION $\ldots \ldots \ldots \ldots \ldots 340$

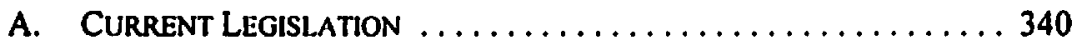

B. Proposed Legisl.ATION $\ldots \ldots \ldots \ldots \ldots \ldots \ldots \ldots \ldots \ldots \ldots \ldots$

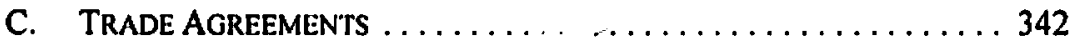

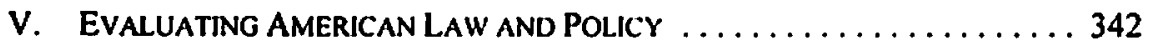

VI. Canadian Regulation of Cross-Border Pharmacy $\ldots \ldots \ldots \ldots 347$

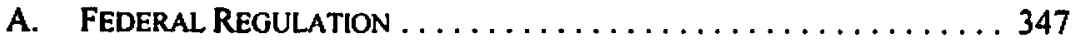

B. College Regulation $\ldots \ldots \ldots \ldots \ldots \ldots \ldots \ldots \ldots \ldots \ldots \ldots \ldots \ldots \ldots$

VII. Evaluating CANadian REgulation .................... 354

VIII. EMERGENT FRAMEWORKS: INTELLECTUAL PROPERTY,

COMPETITION LAW AND ECONOMICS $\ldots \ldots \ldots \ldots \ldots \ldots \ldots \ldots \ldots$

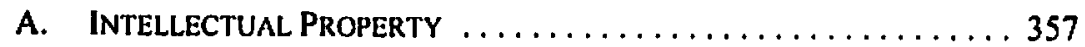

B. Competition Law $\ldots \ldots \ldots \ldots \ldots \ldots \ldots \ldots \ldots \ldots \ldots, \ldots \ldots \ldots$

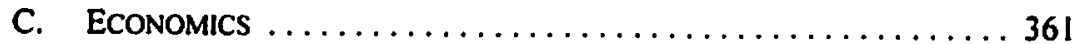

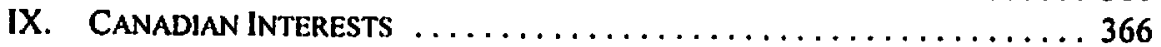

\section{INTRODUCTION}

Cross-border pharmacy is big business - in 2003 and again in 2004 an estimated one million American patients ordered \$1 billion worth of prescription drugs over the Internet from Canadian pharmacies, despite an ostensible U.S. prohibition on drug imports and Canadian pharmacist and physician regulator prohibitions on cross-border pharmacy.' Driven by strong demand, cross-border pharmacy is poised for further growth as more patients and, increasingly, cities and states look to Canada as an escape mechanism from rising U.S. drug costs. $^{2}$

Tony Pugh, "Group of Canadian pharmacies steps into drug re-importation fight" Knight Ridder Newspapers (30 Octobet 2003), online: <htip://webarchive.org/web/20040225183817/htip://www. realcities.com/m/d/krwashington/news/nation/7143731.htm>: J.G. Simith, "“Net Profits" MDCanada (September/October 2004) 34.

Minnesota Senator Mark Dayton donated his salary to funding bus trips for seniors buying prescription drugs in Canada in 2003-2004. "Harper's Index" Harper's Magazine 309:1850 (July 2004) 13. 
Internet-based cross-border pharmacy has reignited a long-standing debate over prescription drug pricing. ${ }^{3}$ Pharmaceuticals are central to health care and yet high costs relative to disposable income and public budgets lead to hard choices between wellness and suffering, even life or death, for patients and policy makers. Drug prices in the U.S. continue to outpace inflation and strain payor resources. The issue is especially pressing in the U.S., where $\mathbf{4 5}$ million people lack prescription drug coverage. The introduction of partial drug coverage for low-income seniors under new medicare legislation promises to ameliorate this lack of access, but analysts have warned that coverage gaps and cost pressures on the program mean that cross-border pharmacy will remain an attractive option for both individuals and public funders. Cross-border pharmacy seems to offer a ready means for easing cost pressures on patients and insurers in the U.S. — but is cross-border pharmacy a legitimate response to U.S. drug prices?

Supporters of cross-border pharmacy argue that current drug import prohibitions unjustifiably limit patient choice and exaggerate risks to patients. They defend the quality of Canadian cross-border Intemet pharmacy services as on par with conventional domestic internet and walk-in pharmacies in the U.S. and Canada. They argue that the potential for harm to patients from rogue Intemet pharmacies should be balanced against the positive safety record of professionally operated "legitimate" cross-border pharmacies and the harm suffered by patients who, but for cross-border pharmacy, could not afford their prescription medication. Cities, states and other public entities providing drug coverage for current and pensioned employees argue that budget constraints and domestic prices leave them with no better option than cross-border pharmacy from Canada and elsewhere.

Opponents of cross-border pharmacy (particularly pharmaceutical firms) argue it exposes patients to unacceptable risk. The U.S. Food and Drug Administration (FDA) argues that cross-border pharmacy sidesteps necessary regulatory oversight and that patients are unduly vulnerable to counterfeiters and other rogue operators. Physician and pharmacist regulators in Canada object to Canadian pharmacists and physicians serving U.S. patients via the Internet and in the absence of in-person consultations between U.S. patients and Canadian physicians (under Canadian law, a Canadian pharmacist can only fill a prescription under the authorization of a Canadian physician; cross-border pharmacies therefore hire Canadian physicians to "co-sign" the prescriptions cross-border customers obtain from their U.S. physicians). Canadian patient advocacy groups also worry that cross-border pharmacy is siphoning pharmacy supplies and human resources away from Canadian patients and, more seriously, will increase political pressure to weaken or eliminate Canadian price controls. ${ }^{4}$ Finally, cross-border pharmacy is criticized on economic grounds as the import of Canadian governmental price controls, which, if applied to the U.S. market from which pharmaceutical firms derive much of their profits, would lead to severely reduced global investment in research and development of new drugs.

1 The accusation that prescription drug manufacturers charge unduly high prices to American consumers dates back at least 30 years; see Milton M. Silverman \& Philip R. Lee, Pills, Profits, and Polirics (Berkeley: University of California Press, 1974).

+ Aidan Hollis \& Aslam Anis, "RX for Canada: Close the Internet Pharmacies" (October 2004) 205 C.D. Howe Institute Commentary, online: C.D. Howe Institute < www.cdhowe.org/pdf/commentar__205. pds. 


\section{The Mechanics and Context of Cross-Border Pharmacy}

Though cross-border sales in North America today appear to be a product of the Internet age, the phenomenon actually dates to the 1970s, when it became popular among border state residents to take "pharmacy tourism" trips to Mexico and Canada (and vice versa) to save costs or to obtain drugs not available domestically." In-person cross-border pharmacy shopping continues today (for example, in 2004 a shortage of flu vaccines in the U.S. led to the marketing of "flu shot cruises" to Vancouver), but at a much lower level relative to Internet-based mail-order transactions.

\section{A. Drug Prices Vary Internationally}

The incentive for cross-border pharmacy arises wherever international differences in price or access exceed the cost or trouble of shopping and shipping. Retail drug prices in OECD nations sort roughly into three levels. The U.S. has the highest prices, with Germany and Switzerland close behind; Australia, Canada, France and the U.K. have intermediate prices; Italy, Spain, Portugal and Japan have the lowest prices. "Cross-border pharmacy, or "parallel trade of drugs," is well established in Europe, though cross-border sales are made between regulated pharmacies and distributors but not directly to the public. ${ }^{7}$ For the most widely prescribed prescription drugs, retail prices are on average 20-30 percent lower in Canada than in the U.S. ${ }^{8}$ Given Canada's proximity to the U.S. (which allows for rapid and low-cost shipping) and its substantially similar drug and pharmacy regulation, cross-border pharmacy on a large scale needed only the development of the Internet as a trusted shopping medium to connect consumer and supplier.

It should be noted that the international hierarchy of drug prices noted above refers to retail prices paid by, or on behalf of, the consumer/patient." In fact, prescription drugs often pass through a number of hands between the manufacturer and the patient and there are a multitude of "drug prices" within a country as bulk purchasers and government bodies use legislative authority or negotiation to set the prices they pay. Comprehensive international pharmaceutical price comparisons are therefore complicated not only by the different drugs,

- Mexican "pharmacies" offering compounds of questionable clinical valuc as well as narcotics and stimulants without a prescription present a particular problem for U.S. Iaw enforcement and pharmacy regulators. See "Border Line Drugs: America's Mexican Medicine" Economist 370:8360 (31 January 2004) 60; see also David J. Cantor. "Preseription Drug Price Comparisons: The Uniled Slales, Canada. and Mexico," Congressional Research Service Report for Congress 98-61E (23 January 1998).

" S. Jacobzone, Pharmaceutical Policies In OECD Countries: Reconciling Social and Industrial Goals. Labour Market and Social Policy - Occasional Papers No. 40 (Paris: OECD. 2000), online: OECD $<$ www, olis.oecd.org/OLIS/2000DOC.NSF/477adc2 I 4b9la685c/2569fa005d0ec $7 / \mathrm{c} 125685 \mathrm{~b} 0057 \mathrm{c5}$

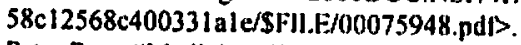

Peter Rost, "Medicines Without Borders" New York Times (30 October 2004) ^19.

Donald L. Barlett \& James B. Steele. "Why We Pay So Much For Drugs" Time Magasine $163: 5$ (2 February 2004) 44: National Legislative Association on Prescription Drug Prices, "Drug Price Comparison" (March 2003), online: <www.nlarx.org/policy/docs/US-CanndianPriceComparison 2003.doc>: John R. Graham. "Prescription Drug Prices in Canada and the United States - Part 3 Retail Price Distribution" (2001) Public Policy Sources. online: Fraser Instilute <http://oldfraser.Iexi.
net/publications/pps/50/inilex.htm|>.

Ernst R. Berndt, "International Comparisons of Pharmaceutical Prices: What do We Know, and Whal Does it Mean?" (2000) 19 Journal of Health Economics 283. 
formulations and dosages used in different countries but also by the varying, and often confidential, prices paid by different payers, including pharmacies, hospitals, HMOS, pharmacy benefit managers, employer consortiums, non-profit associations, private insurers, public insurers and governments. ${ }^{10}$ Secret manufacturer rebates, volume incentive payments and other practices that obscure true prices are common with large-scale transactions. The difference in prices paid by different buyers can be significant: for example, the U.S. Defence Department and Veteran's Administration pay approximately 60 percent of U.S. retail prices, a level on par with Canadian retail prices. " Despite the technical difficulties involved in price comparisons at the wholesale level, however, there can be little doubt that at the retail level served by cross-border pharmacy, Canadian drug prices are significantly lower than those in the U.S.

It should also be noted that this cross-border retail price difference applies only to drugs under patent. Generic drugs actually tend to be priced slightly lower in the U.S., probably because there are, on average, five competing manufacturers per generic drug in the U.S. versus two in Canada. ${ }^{2}$ Though the price difference for generics is probably not enough to support much of a "reverse" cross-border market for individual Canadians, it may represent an under-explored avenue for cost savings for provincial and territorial public drug coverage programs.

Finally, predictions that the introduction of partial drug coverage under Medicare reforms passed in January 2004 would signal the end of demand for cross-border pharmacy have proven incorrect. ${ }^{13}$ Scheduled for full implementation in 2006, the program has been criticized for failing to provide full relief for low-income seniors with high drug costs. A primary point of criticism is with respect to a "donut hole" in coverage: annual drug costs between $\$ 2,251$ and $\$ 5,100$ are unfunded, and about 40 percent of Medicare beneficiaries have annual drug expenditures that exceed $\$ 2,251 .^{14}$ Perhaps more significantly, the enabling legislation constrains the ability of states to restrain drug prices and allows providers to charge co-payments, deductibles and rising premiums, setting the stage for spiralling program costs and the erosion of benefits. ${ }^{\text {is }}$

Patricia M. Danzon, "Making Sense of Drug Prices" (2000) 23:I Regulation 56 (arguing comparisons of aggregate prices between countries provide a weak basis upon which to craft drug price policy). Richard G. Frank, "Prescription Drug Prices: Why Do Some Pay More Than Others Do?" (2001) 20:2 Health Affairs 115, online: Health Affairs <http:/content.healthaffairs.org/cgi/reprinU/20/2/1 15.pdt>. Patricia Danzon, "The Uses and Abuses of International Price Comparisons" in Robert B. Helms. ed.. Competitive Strategies in the Pharmaceutical Industn' (Washington. DC: AEI Press. 1996) 85.

U.S.. Department of Health and Human Services. Prescription Drug Coverage. Spending. Urilization. and Prices (April 2000), online: Department of Health and Human Services <hitp://aspe.hhs.gov/health/ reports/drugstudy/s. <www.aarp.org/bulletin/medicare/Articles/a2003-12-24-newmedicare.html>; "Study: Reimported Drugs Could Fix Medicare Gap" St. Petersburg Times (21 July 2004) 4A. 


\section{B. Why are Patented drug Prices lower in Canada THAN IN THE UNITED STATES?}

\section{PRICE CONTROL LEGISLATION}

Retail drug prices are affected by a number of factors, including consumer wealth, the form and structure of public drug insurance, the willingness of government to negotiate prices and, most importantly, the scope of price control legislation. All OECD countries use price control legislation in some form, though the U.S. does so only for certain federal programs (for example, its Department of Defence). ${ }^{16}$ The other OECD members regulate price on behalf of all residents, either in association with universal publicly funded drug insurance or on behalf of both public and private payors. ${ }^{17}$ Lower Canadian prices on patented prescription drugs are primarily a function of price controls imposed by the Patented Medicine Prices Review Board (PMPRB), an independent quasi-judicial body established under the Patent Act. ${ }^{18}$ The PMPRB was created in 1987 to "[limit] the prices set by manufacturers for all patented medicines, new and existing, sold in Canada, under prescription or over the counter, to ensure they are not excessive."' $T$ The PMPRB's mandate is to prevent manufacturers of patented medicines from charging "excessive prices."

PMPRB regulation applies to the "factory gate" price at which manufacturers sell drugs to wholesalers and distributors. The PMPRB does not regulate downstream wholesale or retail prices. The PMPRB classifies drugs into one of two groups: "breakthrough" drugs with significant clinical benefits over drugs already used to treat the same disease, and "nonbreakthrough" or "me-too" drugs with little clinical superiority over existing drugs. Nonbreakthrough prices are limited such that the cost of therapy with the new drug does not exceed the cost of therapy with already available drugs, with that cost ascertained by reference to prices set by the formulary operated by the province of Ontario for its publicly funded drug insurance programs. ${ }^{2 t}$ Prices of "breakthrough" drugs are generally limited to the median of the prices charged for the same drug in seven other industrialized comparison countries: France, Germany, Italy, Sweden, Switzerland, the U.K. and the U.S. Subsequent price increases for patented medicines are limited to changes in the Consumer Price Index.

State efforts to control prices for public welfare progranss have faced stift opposition from firms. The Maine Rx Program, for example, which mandated a 15 percent discount for low-income plan beneficiaries, was challenged as an unconstitutional intrusion of state power. The program was ultimately upheld by the Supreme Court (Pharmaceutica/ Research and Mfrs. of America v. Walsh, 538 U.S. 644 (S.C. 2003)). See Maine State Law and Legislative Reference Library, "Main Rx." online: <iwww.state.me.us/legis/lawlib/mainerx.htm>. Firms were successful, however, in lobbying Congress to include provisions in the new Medicare drug benefit legislation, scheduled to come into effect in 2006, that prevent states from mandating discounts on drugs paid for by medicare. Jacobzone, supra note 6.

R.S.C. 1985, c. P-4, ss. 79-100.

Patented Medicine Prices Review Board, "Frequently Asked Questions," online: <www.pmprbcepmb.ge.ca/english/view.asp? $x=272 \#$ i>.

2" Supra note 18, s. 83.

$\therefore$

A formulary is a list of drugs that an insurer will cover as well as the prices it will pay. 
The price of a patented drug may at no time exceed the highest price for the same drug in the seven comparator countries. ${ }^{22}$

\section{PUBLIC Formularies}

As mentioned, PMPRB price regulation for non-breakthrough (i.e. most) drugs is based on the province of Ontario's public drug insurance formulary.$^{23}$ Ontario formulary prices are based on clinical evaluations and cost-benefit comparisons between similar drugs; increases in the price of a drug are restrained by regulation. ${ }^{24}$

\section{OTHER FACTORS}

Lower Canadian prices also reflect lower costs of selling prescription drugs in Canada. One study suggests that as much as one-third of the cross-border price differential in 1990 could be ascribed to the higher cost of insuring against, defending and paying out on product liability claims in the U.S. ${ }^{25}$ Direct-to-consumer (DTC) advertising is another cost of selling in the U.S. market. From 1997 through 2001 , spending on DTC advertising of prescription drugs rose nearly 150 percent. $^{26}$

The lower spending power of Canadians may also contribute to cross-border price differences. ${ }^{27}$ Software, over-the-counter drugs and automobiles have been cited as examples of consumer goods priced lower in Canada for this reason. ${ }^{28}$ Finally, the relative price advantage for U.S. consumers buying from Canada will be affected by the currency exchange rate.

\section{The logistics of a Cross-Border Pharmacy Transaction}

Some Internet sites offer to bypass the need for a patient to provide a prescription through "Internet prescribing," which relies on patient responses to an online questionnaire. The Canadian cross-border pharmacy industry does not condone Internet prescribing. Instead,

Patented Medicine Prices Review Board, "Compendium of Guidelines. Policies and Procedures: Schedulc 2 - Therapeutic Class Comparison Test," online: <www.pmprb-cepmb.gc.cr/english/ view.asp? $\mathrm{x}=148 \mathrm{\& mp}=135>$.

" Ibid.: Canadian Institule for Health Information. "Drug Spending in Canada Still on the Rise. Public Sector's Share Increasing. Reports CIHI" (22 June 2004), online: <www.secure.cihi.ca/cihiweb/ dispPage.jsp?cw_page=media_22jun2004_e $>$.

Anne M. PausJenssen, Peter A. Singer \& Allan S. Detsky. "Ontario's Formulary Committec: How Recommendations Are Made" (2003) 21 PharmacoEconomics 285

: Richard L. Manning. "Products Liability and Prescription Drug Prices in Canada and the United States" (1997) 40 J. L. \& Econ. 203.

: Martin T. Galart ef al., "Examining The FDA's Oversight of Direct-To-Consumer Adverising" (26 February 2003) Health Aftairs Web Exclusive at W3-120. online: Itealth Aflairs <http://content health affairs.org/cgi/reprint/hlthafT.w3.120vl>.

" Patricia M. Danzon. Price Comparisons for Pharmacenucals: A Reviell of US and ('ross-Nanional Studies (Washington. D.C.: AEl Press. 1999); Jolın R. (iraliam \& Beverley A Robson. "Preseription Drug Prices in Canada and the Uniled Stales - Part $1: A$ Comparative Survey" Public Policy Serurces, No. 42 (Vancouver: The Fraser Instilute. September 2000).

:x John R. Graham \& Michacl Walker. "Why are Drug Prices Lower in Canada?" (200)10) 6 American Joumal of Managed Care 745: Graham \& Robson. ibid 
patients are required to provide prescriptions obtained from their U.S. physician in the usual way, with a visit to the doctor's office. Some patients use U.S. storefront operations that accept prescriptions and then order the drugs from Canada for patients, but most cross-border pharmacy patients place their orders directly through the Internet. A number of informational sources, including websites operated by state and city governments and senior citizens' advocacy groups, provide information on selecting a Canadian cross-border pharmacy. The major pharmacies require the patient to fill out a medical questionnaire, primarily directed at determining what other medication the patient is taking and other information a pharmacist would typically ask in relation to the prescription. The patient is required to indicate consent to the cross-border purchase and submit a credit card payment. Finally, the patient is required to mail in the paper prescription form provided by the physician or arrange to have the prescription faxed to the pharmacy directly.

At the Canadian pharmacy, a Canadian physician (usually paid a per-prescription fee) reviews the online order and medical information and checks it against the written prescription. ${ }^{29}$ The physician then re-writes ("co-signs") the prescription and the pharmacist dispenses the drug and mails it to the patient along with the original prescription.

\section{Canadian Cross-Border Pharmacies}

Of the over 7,000 pharmacies in Canada, approximately 270 do business at least in part over the Internet. ${ }^{30}$ The cross-border pharmacy industry, moreover, is concentrated: a dozen pharmacies account for 90 percent of all sales."

The major Canadian cross-border pharmacies are provincially licensed and have both a walk-in store and an online presence. A very few cross-border operations describe themselves as "facilitator sites" - they operate websites, accept orders and forward prescriptions to licensed pharmacies for dispensing. Facilitator sites are particularly controversial, especially within a cross-border industry intent on demonstrating trustworthiness, because they argue they are outside the jurisdiction of pharmacy regulators since they do not serve Canadian patients.

Many Internet pharmacies (cross-border and domestic, U.S. and Canadian) self-regulate through accreditation. Examples of privately operated accreditation services that verify compliance with regulatory requirements and "best practices" guidelines are the Verified Internet Pharmacy Practice Sites (VIPPS) program, the Internet and Mail Order Pharmacy Accreditation Commission (IMPAC), the North American Pharmacy Accreditation Commission (NAPAC) and PharmacyChecker.com. These are for the most part directed at domestic U.S. Internet pharmacies and not cross-border pharmacies based in Canada. The

Usually a per-prescription fee of $\$ 710$ \$15. A physician may co-sign hundreds of prescriptions a day. Health Canada. "Summary Report of the Compliance Inspections of Canadian Pharmacy Sites Involved in the Sale of Prescription Drugs Via the Internet.or Via Distance Dispensing" (November 2004). online: Health Canada <www.hc-sc.gc.ca/dhp-mps/compli-conform/info-prod/drugs-drogues/inspect-
pharma/internet_e.hıml>. audience member (Symposium: Cross-Border Internet Pharmacy - Public Policy Implications, Toronto. 9 March 2004) [unpublished]. 
cross-border pharmacy industry trade group, the Canadian Internet Pharmacy Association (CIPA), operates a certification program for its members. ${ }^{32}$

Customers seeking a Canadian cross-border pharmacy are cautioned, however, that a number of rogue operators falsely advertise themselves as Canadian, and consumers are advised to confirm that Internet pharmacies display clickable links to College of Pharmacy certificates indicating their status as registered Canadian pharmacies."

\section{E. Who are the Cross-Border Pharmacy Customers?}

\section{INDIVIDUAL PATIENTS}

Most cross-border pharmacy transactions have been individual sales to uninsured seniors most affected by high drug prices. Seniors are, of course, the major consumers of drugs for chronic conditions: seniors living in the community take on average 4 l/2 prescription drugs at any one time, primarily for treatment of heart disease, diabetes, high cholesterol and arthritis. ${ }^{34}$ That drug prices are problematic for many U.S. patients is illustrated by the recent finding of a seniors advocacy group that more than one-third of uninsured seniors with diagnosed congestive heart failure, diabetes or hypertension skip doses and one-fourth fail to fill their prescriptions at all because of cost. ${ }^{35}$

\section{Cities AND States}

Faced with rising costs, a number of U.S. cities and states have looked to Canada for drug coverage insurance provided to employees, low-income residents, seniors and other groups. ${ }^{36}$ Manitoban cross-border pharmacies have hosted fact-finding delegations of public officials from Minnesota, Illinois, Wisconsin, North Dakota, New Hampshire and California." Missouri, Illinois and Wisconsin run drug import programs. ${ }^{38}$ Under a Minnesota state employee health insurance program, shipping fees are reimbursed and the usual co-payment is waived for 45 of the most popular drugs without generic alternatives if the employee buys

Canadian Intemet Pharmacy Association, online: <www ciparx.ca>.

" Riva Richmond \& Greg Groeller. "Many Canadian Drug Web Sites Fake" Dow Jones Newswire (13 June 2005).

14 Janice B. Schwartz, "Geriatric Clinical Pharmacology" in William N. Kelley, Textbook of Imternal Medicine. 3d ed. (Philadelphia. PA: Lippincott-Raven, 1997) 2547 at 2553.

John D. Piette, Michele Heisler \& Todd H. Wagner, "Cost-Related Medication Underuse Among Chronically III Adults: the Treatments People Forgo, How Ofen, and Who Is at Risk" (2004) 94 American Journal of Public Health 1782.

John Kasprak, "Prescription Drug Importation" (R0463) (2004), Connecticut Office of l.egislative Research, online: <inww.cga.ct.gov/2004/rpd2004-R-0463.htm>.

"The Canadian Press. "U.S. Oficials to Visit Web Pharmacies in Winnipeg: Suppliers Eager to Prove Inventory Secure" Edmonton Journal (26 July 2004) A9. <umw.senale.state.mo.us/04INFO/joumals/DAY07.html>; U.S., Office of Special Advocate For Prescription Drugs, Illinois Department of Central Management Services, Report on Feasibility of Employees and Retirees Safely and Effectively Purchasing Prescription Drugs From Canadian Pharmacies (27 October 2003), online: <www.affordabledrugs. il.gov/pdf/SpecialAdvocateCanadian 10 27-03Final.pds. 
from a state-approved Canadian Internet pharmacy ${ }^{39}$ Massachusetts, Rhode Island, Vermont and other states have commissioned feasibility studies or otherwise expressed interest in importing drugs from Canada. ${ }^{40}$ California and New Hampshire have voiced interested in imports for prisoners." California passed a bill authorizing imports on behalf of residents before Governor Schwarzenegger vetoed the legislation. ${ }^{42}$ States including Illinois, Rhode Island, Minnesota and California are considering legislation that would require public drug plans to include bids from Canadian Internet pharmacies for all drug contracts. ${ }^{43}$

Wisconsin, Minnesota, North Dakota and New Hampshire provide links to Canadian pharmacies on their state websites." California is considering listing Canadian pharmacies on the state board of pharmacy website. ${ }^{45}$

Some states have taken legal action to pursue their interest in cross-border pharmacy. Illinois filed a "citizen petition" with the FDA in April 2004, formally requesting permission to buy Canadian drugs under that state's proposed import program. ${ }^{46}$ In August 2004, Vermont announced its intent to file suit against the FDA for what it says is an unreasonable refusal to authorize its import program. ${ }^{37}$

Interestingly, imports by cities and other large public programs are controversial within the cross-border pharmacy industry, which is sensitive to fears that large-scale exports will threaten Canadian domestic supplies. ${ }^{48}$ The Canadian Internet Pharmacy Association (CIPA), based in Manitoba and a promoter of the industry, has chosen not to fill municipal or state orders, but this position is clearly not shared by all cross-border pharmacies. ${ }^{49}$ Springfield, Massachusetts, was the first city to import drugs for its employee program starting in 2002; Montgomery, Alabama, followed shortly thereafter. As of July 2004, Canadian pharmacies

"Plan Offers Cheaper Canadian Drugs Free" Los Angeles Times (14 May 2004) Al8.

Christopher Rowland, "AG pushes for medicine from Canada" The Boston Globe (14 October 2003),

online: <www,boston.com/news/local/massachusetts/articles/2003//0/14/ag_pushes_for_medicine_ from_canada>.

The FDA rebuffed an inquiry from the Deputy Altorney (ieneral of California. letler from William $k$. Hubbard, Associate Commissioner for Policy and Planning. Food and Drug Administration, to Gregory Gonot (25 August 2003), online: <www. pbrx.con/FDANews9.htm>.

Bill Ainsworth, "Veto kills eflort to open door to Canadian drugs". San Diego Union-Tribune (1 October 2004) Al. Supra note 37.

See e.g. online: Minnesota RxConnect Online <www.state.mn.us/portal/mn/jsp/home.do?agency= $\mathrm{R} \times 7>$.

" Gabrielle Banks, "Agency Opposes Online Drug Bill" los Angeles Times (4 August 2004) B12.

ע. U.S., Illinois Office of the Governor, News Release, "Gov. Blagojevich and Attomey General Madigan file Citizen's Petition with FDA on behalf of Illinois prescription drug consumers, Demands response on drug importation" (8 April 2004), online: Government of Illinois <www.illinois.gov/Press Releases/ShowPressRelease.cfm?SubjectiD=19\&RecNum=2931).

U.S. Vermont Governor Jim Douglas. News Release, "(invernor \& Allorney General to Sue FDA Over Drug Reimportation" (10 August 2004), online: Government of Vermont <www.vermont.gov/tools/ whatsnew2/index.php?topic $=$ GovPressReleases\&id $=834 \& v=$ Article $>$.

4\% Bernard Simon, "Canada deals blow to cheap drug imports for US" Financial Times (18 October 2004) 
were supplying at least 36 cities and counties, including the county where the FDA is headquartered. ${ }^{\text {so }}$

\section{American Regulation of Cross-Border Pharmacy}

\section{A. Federal Legislation}

The U.S. legislation central to cross-border pharmacy is the Federal Food, Drugs, and Cosmetic $\mathrm{ACt}$, which prohibits the re-importation of drugs manufactured in the U.S. by anyone other than the manufacturer, as well as importation of prescription drugs lacking FDA approval." The FFDCA requires FDA approval of a drug's active ingredient as a safe and effective treatment as well as oversight and approval of manufacturing, packaging, labelling, storage, shipment and chain of custody.

Most cross-border drugs are "unapproved" in that they fail FDA labelling and chain of custody requirements. While Health Canada has jurisdiction over the manufacturing, packaging, labelling, storage, shipment and chain of custody for prescription drugs sold in Canada, including those sold by cross-border pharmacies with operations in Canada, there is no provision in the FFDCA (aside from that found in a latent legislated import framework discussed below) for recognition of Health Canada regulation. Firms are vested with control over the use of FDA-approved labels for their products and do not allow their use by Canadian distributors. ${ }^{\$ 2}$

\section{B. NON-ENFORCEMENT AGAINST INDIVIdUALS}

Cross-border prescription drugs sales take place despite the FFDCA import prohibition because the FDA does not enforce the legislation against individuals who have personal supplies of drugs shipped directly to them. The FDA claims that intercepting personal crossborder drug shipments would overly strain its resources, describing as particularly onerous, given the volume of sales and the storage and handling requirements of prescription drugs, a requirement under U.S. customs regulations that intercepted shipments be set aside and the intended recipient notified and given an opportunity to demonstrate that the shipment should be released. ${ }^{53}$ The FDA describes its policy as follows:

Because the amount of merchandise imported into the linited States in personal shipments is normally sinall. both in size and value, comprehensive coverage of these imports is normally not justified... FDA personnel may use their discretion to allow entry of shipments of violative FDA regulated products when the quantity

"Maine city approves Canadian drug option" Associated Press (25 June 2004), online: RxDirector.com <rxdirector.com/news\& 11 html $>$. "Boston mayor not dropping Canada drug plan" Associated Press (18 December 2003), online: CNN <www.con.com/2003/HF.AL.TH/12/18/canada.drugs.ap/index. html>: "FDA trying lo stop Canadian drug imports: Officials hope Boston and N.I1. will abandon plans" Associated Press (16 December 2003), online: MSNBC <msnbc.msn.com/id/3732019>.

21 U.S.C. $\$ 381(2004)[F F D C A]$.

Jacobzone, supra note 6.

U.S. Senate Committee on Commerce, Science and Transporation. Subcommittee on Consumer Affairs, Foreign Commerce and Tourism, testimony by William K. Hubbard, Senior Associate Commissioner for Policy, Planning and Legislation, Food and Drug Administration (5 September 2001). online: U.S. Department of Health \& Human Services <imww.hhs.gov/as//testily/t010905.html> 
and purpose are clearly for personal use, and the product does not present an unreasonable risk to the user.... Although FDA may use discretion to allow admission of certain violative items, this should nor be interpreted as a license to individuals to bring in such shipments....

In deeiding whether to exercise discretion to allow personal shipments of drugs or devices, FDA personnel may consider a more permissive policy [when] ... the individual seeking to import the product affirms in writing that it is for the patient's own use (generally not more than 3 month supply) and provides the name and address of the doctor licensed in the U.S. responsible for his or her treatment with the product. ${ }^{54}$

In practice, the FDA almost never requires that a shipment indicate it is for personal use or that the name of the prescribing physician be supplied, although some cross-border pharmacies include this information. ${ }^{55}$

\section{FOOd ANd DRIG AdMinistration Enforchiment AGaINST AMERICAN STOREFRONT OPERATIONS}

The FDA has been more aggressive against storefront operations. However, only a few cases have been litigated, most matters have not progressed beyond service of cease-anddesist letters, and new stores continue to open, sometimes with the blessing of local governments.

The FDA's first significant success against U.S. storefront operations was in 2003 in U.S. v. RxDepot. ${ }^{57}$ The agency obtained a court injunction to shut down the rapidly expanding franchise following an operation in which undercover agents were able to obtain a drug with Health Canada- (but not FDA)- approved labelling, and a drug manufactured in Costa Rica and otherwise FDA-approved in all respects except that it had been imported into the U.S. by someone other than the manufacturer. ${ }^{38}$ The court held that it could not consider evidence of safeguards put in place by RxDepot to check prescription accuracy, verify product authenticity and maintain proper storage and handling procedures, or indeed to consider any evidence on the safety of RxDepot practices. The court also accepted as accurate, but held that it could not consider, evidence that a significant number of seniors and the uninsured were having trouble filling prescriptions because of domestic drug prices and that these patients would be harmed by an inability to use the cross-border services provided by RxDepot. Instead, the court indicated that U.S. drug pricing policy and the wisdom of the import restriction were matters for a political, not legal, forum.

U.S., Food and Drug Administration, Office of Regulatory Alfairs. "Coverage of Personal Importations," online: FDA < www.fda.gov/ora/compliance_ref/rpm_new2/ch9pers.html>.

Interview of David MacKay ( 9 March 2004) at Symposium: Cross-Border Internet Pharmacy — Public Policy Implications, supra note 31.

*. Gary Gately. "Despitc U.S. Cracklown. Cities Still Offer Imported Meds"/ /eallh DayNews (29 January 2004), online: Health Central <www.healtheentral.com/11ewsdetail/408/517|91.htm|>: U.S., Food and Drug Adminstration "Warning Letler" from David J. Horowitz. FDA. to Noel Thomas Curb, Tom Lanham \& Mike Strickland (22 January 2004), online: FDA <inww.fda.gov/cder/warn/2004/ ExpediteRx.pdis.

$37 \quad 290$ F.Supp.2d 1238 (N.D. Okla. 2003)

s RxDepot has since reincarnated as an Internet-prescriplion pharmacy. offering to sell U.S.-sourced prescription drugs to patients lacking a prescription and based on RxDepot physicians' review of patients' answers to website questionnaires. 


\section{The Food and Drug Administration and States and Cities}

In responses to formal inquiries from local governments, the FDA has strenuously objected to proposed city and state import programs and warned that governments and officials who encourage the use of cross-border pharmacy risk incurring a number of civil and criminal penalties. ${ }^{.9}$

As with its non-enforcement policy towards personal imports, however, the FDA has not followed through on threats to prosecute states and cities. Following a series of closed-door meetings with state and city officials, the FDA announced in early 2004 that it would follow a "soft" approach and negotiate with cities and states intent on importing. ${ }^{60}$ Nonetheless, the relationship between the FDA and some pro-import states has been strained. ${ }^{61}$

\section{E. State Regulation}

In sharp contrast to the formal opposition of the FDA to drug imports from Canada, many governments at a local level are actively supporting and engaging in cross-border pharmacy. Reacting to the demands of their constituencies and the limits of public budgets, these states and municipalities have endorsed cross border pharmacy in a variety of ways, including encouraging residents to use specified Canadian pharmacies and purchasing drugs for state and city employee benefit and medicare programs.

Since the states lack jurisdiction over cross-border drug imports, regulation at the state level is primarily through pharmacy legislation enforced in cooperation with state professional boards. Forty-two states require pharmacies based outside the state to register with their boards of pharmacy before selling drugs to residents. ${ }^{62}$ Of these, 12 states believe they have legal authority to license foreign pharmacies to sell drugs to state residents despite the FFDCA prohibition. ${ }^{63}$ In practice, states opposed to cross-border pharmacy have little recourse against unregistered out-of-state pharmacies that sell to individual patients over the

For example, in a letter, supra note 41, the FDA warned:

A court can enjoin violations of the FFDCA under 21 U.S.C. $\$ 332$. A person who violates the FFDCA can also be held criminally liable under 21 U.S.C. $\$ 333$. A violation of 21 U.S.C. $\$ 331$ (a), (d), or (t) may be prosecuted as a strict liability misdemeanour offence. See United States v. Dotterweich, 320 U.S. 277, 284 (1943); 21 U.S.C. \$333(a)(1). Any such violation that is committed with intent to defraud or mislead or after a prior conviction for violating the FFDCA may be proseculed as a felony under 21 U.S.C. $\$ 333(\mathrm{a})(2)$. Separately, it is also a felony to knowingly import a drug in violation of the "American goods returned" provision of 21 U.S.C. $\$ 381$ (d)(1). Sec 21 U.S.C. $\$ 333$ (b)(1)(A).

Those who can be found civilly and criminally liable include all who cause a probibited act under the FFDCA. 21 U.S.C. $\$ 331$ ("The following acts and the causing thereof are hereby prohibited"). Those who aid and abet a criminal violation of the liFDCA, or conspire to violate the FFDCA, can also be found eriminally liable under 18 U.S.C. $\$ 2$ and 371 Jeffrey Krasner. "FDA eases stance on importing medicines" The Boston Globe (24 October 2003), online: boston com <iwww.boston.com/business/globe/articles/2003/10/24/fda_eases_stance_on_ importing_medicines $/>$. 
Internet, both because these transactions are almost impossible to detect and because of the complexity of the trans-national jurisdictional issues involved.

\section{AMERICAN PRESCRIPTION DRUG IMPORT LEGISLATION}

\section{A. Current Legislation}

Little recognized is that the $F F D C A$ actually contains a framework for legal prescription drug imports from Canada. Under this framework,

the Secretary [of Health and Hunzan Services, parent agency to the FDA] slaall by regulation grant individuals a waiver to permit individuals to import into the United States a prescription drug that:

(A) is imported from a licensed plarmacy for personal use by an individual, not for resale, in quantitics that do not exceed a 90-day supply:

(B) is accompanied by a copy ol' a valid prescription;

(C) is imported from Canada, from a seller registered with the Secretary:

(D) is a prescription drug approved by the Secretary ...:

(E) is in the form of a final linislted dosage that was manufactured in an [approved facility]: and

(F) is imported under such other conditions as the Secretary determines to be necessary to ensure public safely. ${ }^{\text {of }}$

Similarly, the Secretary is to permit commercial imports that meet specified labelling, chainof-custody and quality control conditions. The legislation also includes a procedure for ending the program anytime after one year if the Secretary, following a detailed procedure and based on substantial evidence, determines that the risks from imports outweigh their benefits. ${ }^{\text {ss }}$

\section{U.S.C.A $\$ 384(j)(3)$.}

21 U.S.C.A. $\$ 384$ (I)(2)(B) prevents the Secretary from cnding the import program unless, after holding public hearings, the Secrelary:

(i) (I) determines that it is more likely than not that implementation of this section would result in an increase in the risk to the public health and safety;

(II) identifies specifically, in qualitative and quantitative terms, the nature of the increased risk:

(III) identifies specifically the causes of the increased risk; and

(IV) (aa) considers whether any measures can be taken to avoid, reduce. or mitigate the increased risk: and

(bb) if the Secretary deterinines that any measures described in item (aa) would require additional statutory authority, submits to Congress a ceport describing the legislation that would be required;

(ii) identifies specilically, in qualitative and quantitative terms, the benefits that would result from implementation of this section (including the benefit of reductions in the cost of covered products to consumers in the United States, allowing consumers to procure needed medication that consumers night not otherwise be able to procure 
The legislative provisions providing for this import framework, however, only come into force if the Secretary of Health and Human Services first certifies that imports would "(A) pose no additional risk to the public's health and safety and; (B) result in a significant reduction in the cost of covered products to the American consumer. " ${ }^{\prime 6}$ The current Secretary has thus far refused to grant the required certification. ${ }^{67}$

\section{B. Proposed legislation}

Cross-border pharmacy advocates in Congress, frustrated with the Secretary's refusal to certify imports, have put forward a number of bills that would remove the certification requirement and address shortcomings in existing drug import legislation. ${ }^{68}$ For example, under the foremost proposed legislation, firms would be required to manufacture new drugs to the same dosage strength, formulation and appearance in at least half of the countries from which imports are permitted unless the firm can show the difference is required to improve safety or efficacy or is required by the health regulators in that country. Patent rights (discussed below) would be deemed to be exhausted internationally and therefore not be a legal instrument for firms to use against importers. ${ }^{69}$ Drug firms would also be forbidden from discriminating in pricing between registered importers or exporters and foreign domestic suppliers, refusing to do business with cross-border distributors, reducing supplies of cross-border drugs or "engag[ing] in any other action that the Federal Trade Commission determines to unfairly restrict competition under section 804 of such Act." ${ }^{170}$ Imports would be permitted from Canada, Australia, members of the EU, Japan, New Zealand and Switzerland.

without foregoing other necessities of life): and

(iii) (l) compares in specifie terms the detriment identified under clause (i) with the benefits identified under clause (ii); and

(II) determines that the benefits do not outweigh the detriment.

21 U.S.C.A. $\$ 384$ (1)(1).

Legislation providing for regulated exceptions to the general prohibition on imports was first passed in 2000. The Medicine Equiny and Drug Safery' Acr of 2000 (2I U.S.C. $\$ 384$ (2000)) established (subject to Secretary certification) a program allowing imports from specified countries, including Canada, of drugs that have active ingredients approved by the FDA. At the time. Internet pharmacies were just beginning to establish themselves and cross-border pharmacy was primarily a matter of in-person health tourism; imports were expected to be primarily at the wholesale level. Rather than the current emphasis on safety, political attention focused on consumer cost savings. The then-Secretary refused to implement the import program because of doubts that, as structured, it could deliver hoped-for savings. Firms could deny potential importers access to required labels and, most importantly. could limit supplies to overseas distributors or require importers to charge retail prices that eliminated the Canadian price advantage. The legislation also only authorized imports for a five-year period, potentially limiting the number of wholesalers willing to invest in entering and competing in the import market. Under the current framework, manufacturers cannot deny importers the use of FDA labels and there is no automatic sunset. Proposed legislation addresses price imanipulation.

U.S., Bill S. 2328, Pharmaceutical Market Access and Drug Safen' Act of 2004, 1081h Cong. 2004. online: <http://homas.loc.gov/cgi-bin/query/z?c108:S.2328.1S:>.

Section 27(h) of Bill S. 2328 reads: "ll shall not be an act of infringement to use, offer to sell, or sell within the United States or to import inlo the United States any patented invention under section 804 of the Federal Food. Drug, and Cosmetic Act that was lirst sold abroad by or under authority of the owner or licensee of such patent." Ibid.

Jbid., s. 27(a)(11). 


\section{Trade AGreEments}

Even as Congress considers authorizing cross-border pharmacy (not only from Canada but also other countries), opponents of cross-border pharmacy in U.S. trade offices have undertaken a global campaign to curtail exports from lower-priced countries. U.S. trade representatives have negotiated a number of bilateral agreements with potential cross-border pharmacy source nations restricting them from re-exporting drugs and supplying U.S. consumers. Free Trade Agreements (FTAs) between the U.S. and Australia, Morocco and Singapore strengthen the ability of patent holders to place restrictions on re-exports of drugs to the U.S. or any other country. ${ }^{71}$

U.S. proponents of cross-border pharmacy worry that restrictions like these will be incorporated in future FTAs with other potential cross-border pharmacy source nations, undermining or eliminating the potential for drug imports as contemplated in the current and proposed legislation. ${ }^{72}$ For Canadians, restrictive FTAs between the U.S. and other countries reduce the number of countries that can serve as alternative suppliers, both for cross-border pharmacy purposes and for the domestic Canadian market, with potentially worrying effects on long-term international drug pricing dynamics.

\section{Evaluating american law and Policy}

Assessing the legitimacy of cross-border pharmacy appropriately starts with attention to patient safety, and this has been the primary framework for debate over its legitimacy. Safety regulators in both Canada and the U.S. have asserted that patient safety is unduly compromised by cross-border pharmacy, citing examples of substandard drug shipments, inadequate labelling, and other problems.

A statement by the National Association of Boards of Pharmacy (NABP) ${ }^{73}$ (not a regulatory body) typifies the safety justification for prohibiting imports:

U.S., Oflice of the United States Trade Representative. U.S. -Ausiralla Free Trade Agreemen (2004), art. 17.9(4), online: Oflice of the United States Trade Representative <www.ustr.gov/Trade Agreements/Bilateral/Australia_FTAFinal_Text/section_Index.html $>$. See also Industry Functionai Advisory Committee on Intellectual Propenty Rights for Trade Policy Matters (IFAC-3), "The U.S.Australia Free Trade Agreement (I.TA): The Intellectual Property Provisions" (12 March 2004), report to the President, the Congress and the United States Trade Representative, online: Office of the United States Trade Representative <www.ustr.gov/assets/Trade_Agreements/Bilateral/ Australia_FTA/Reports/asset_upload_file813_3398.pdit>; U.S. Ofrice of the United Stales Trade Representative. United States-Morocco Free Trade Agreement (2004). art. 15.9(4), online: Office of the United States Trade Representative < inww.ustr.gov/issets/Trade_Agreements/Bilateral/Morocco FTA/FInal_TexVasset_upload_file 118_3819.pdiS: U.S. Office of the United States Trade Representative. United States-Singapore Free Trade Agreemen (2003), ant. 16.7(2), online: Office of the United States Trade Representalive <www. ustr.gov/assets/Trade_Agreements/Bilateral/Singapore_ FTAFrinal_Texis/asset_upload_file708_4036.pdis.

" Christopher S. Rugaber. "Bilateral Agreements Provision in Australia FTA Could Conflict With Drug Reimport Bill, House Member Says" (July 2004) BNA International Trade Reporter, online: <http://lists. essential.org/pipermail/ip-health/2004-July/006650.html>. 
The distribution by unregulated drug outlets of expired, contaminated, subpotent. superpotent and counterfeit drugs is a significant potential danger linked to foreign medications. Foreign dispensers may provide patients with incorrect or contraindicated medications, incorrect strengths, or medications without adequate directions for use. Absent regulation from the state boards of pharmacy, foreign drug outlets may not have implemented the appropriate standards and safeguards to prevent such occurrences. ${ }^{74}$

The American Pharmacists Association (also not a regulatory body) has made similar assertions, though it might be noted that the financial incentives of U.S. pharmacists are not aligned to cross-border pharmacy unless the pharmacists can themselves import and sell Canadian drugs."

These safety arguments, however, treat "foreign dispensers" as a homogenous group and grossly mischaracterize cross-border pharmacies in Canada. ${ }^{76}$ The FDA is also guilty of tarring with an overbroad brush. Its primary evidence for the "dangerous" nature of foreignsourced drugs was obtained from two investigations conducted in 2003, during which the FDA seized several hundred individual mail packages that appeared to contain prescription drugs from overseas." The first raid, in July, focused on mail from a number of countries suspected to be sources of imported drugs, including Canada, Mexico, India, Thailand and the Philippines. The second raid, in November, focused on mail shipments from Canada and Mexico. In its report summary and public announcements, the FDA described intercepted drugs as "unapproved," "inadequately labeled or packaged," "intended for veterinary use," "carrying risks that required initial patient screening and/or monitoring" or "controlled substances." Notably, however, the "unapproved" drugs from Canada were all in fact Health Canada-approved equivalents to FDA-approved drugs (i.e. drugs a patient would receive in Canada), and the FDA did not specify whether any of the drugs that were "inadequately labeled or packaged," "intended for veterinary use," "carrying risks that required initial patient screening and/or monitoring" or "controlled substances" were even from Canada. ${ }^{28}$

Following a more detailed investigation, in June 2004 the U.S. General Accounting Office (GAO) released its study of cross-border pharmacy, which concluded that ordering from Canadian Internet pharmacies posed fewer risks than ordering from Internet pharmacies

NABP, supro note 62. The NABP laments that too many U.S. patients cannot aftord to fill prescriptions and notes that "[u]ntil there is equity in the pricing of prescription medications, it may be impossible to completely stop US patients from obtaining medications from Canada. Mexico. and other countries." In its position paper, the NABP does not consider whether a legalized. regulated impon regime could address safety concerns, noting only that current regulation and enforcement efforts potentially allow rogue operators to prey on unsuspecting consumers.

American Pharmacists Association. "On Canadian Prescription Drug Importation: Is There a Satety Issuc?" testimony submitted to the Human Rights \& Wellness Subcommittec. U.S. Government Retiom Committee (12 June 2003), online: <http:/72.14.104/search?q=cache:In8h4J24Z14:https:/www aphanet.org/govuSTMT_HouseGovt.pdf+\%22American+Pharmacists+Association $\% 22+$ and $\% 22$ canadian+prescription+drug+importation $\% 22$ human+rights $\% 22 \& h l=c n>$.

3. U.S., Food and Drug Administration. "Buying Prescription Medicines Online: A Consumer Sality Guide." online: FDA < uww. fda.gov/cder/consumerinfo/buyOOnlineGuide_text.htm>

$" \quad$ National Association of Boards of Pharmacy. News Rele:tse. "NABP/FDA Public Salety is at Risk with Foreign Drug Impontalion" (27 January 2004), online: <www nabp.ne/whatsnew/pressreleases/wchl'R asp?idValue $=181>$. 
elsewhere, including from some Internet pharmacies located in the U.S. ${ }^{79} \mathrm{GAO}$ investigators purchased drugs from Internet pharmacies in the U.S., Canada, Mexico, Spain, Thailand and seven other countries. All 18 Canadian pharmacies investigated required consumers to supply a physician-written prescription; that requirement was met by only five of 29 U.S. pharmacies and was not met by the other foreign pharmacies. Prescriptions filled in Canada and the U.S. came with labels from the dispensing pharmacy and generally included patient instructions and warnings. The biggest problem investigators noted was that drugs shipped from Canada did not have FDA approval for use in the U.S. due to labelling differences or from being manufactured in a non-FDA-approved (though Health Canada-approved) plant. The active ingredients were chemically identical to those in FDA-approved drugs. Production and labelling conformed to Health Canada requirements. ${ }^{80}$

Similarly, in November 2004 the Health Products and Food Branch Inspectorate of Health Canada released the results of a cross-country inspection of a very small sample of Internet pharmacies, including cross-border pharmacies, selected for selling large volumes of prescription drugs." The report concluded that, overall, "pharmacy activities were in compliance with the Food and Drugs Act and Regulations, and that products being sold by the pharmacies were approved for sale in Canada." $\$ 2$ The inspection did find some areas of non-compliance with applicable regulations, but these were not so serious as to merit more than a warning.

The GAO and Health Canada reports supports a view that the FDA's broad wamings on the danger of drug imports from all parts of the world are inaccurate when applied to crossborder pharmacy from Canada. The GAO report highlights the distinction between Canadian pharmacies that sell mainstream medications and less reputable businesses, often based in less well-regulated regions (though portraying themselves with alarming frequency as Canadian) that disregard drug safety practices or market lifestyle or even abused drugs. Given the high volume of sales from Canada and the intense interest of pharmaceutical firms in locating evidence of harm with which to discredit cross-border pharmacy, the absence of much evidence of harm from the major Canadian cross-border pharmacies identified in the $\mathrm{GAO}$ report is telling.

Similarly, suggestions that Internet pharmacy is rife with rogue operators fail to recognize the character and dynamics of the Internet as a marketplace. Internet pharmacies, of which cross-border pharmacies are a subset, fall into two non-overlapping groups: licensed operations that adhere to professional standards expected of conventional pharmacies, and online companies that ignore legal requirements in selling lifestyle and recreational drugs. In public statements intended to dissuade patients from using cross-border pharmacy, the FDA often conflates rogue pharmacies with licensed sites. ${ }^{83}$ While rogue operations are a

$r$

Mark Sherman, "U.S. Congress investigation finds few problems at Con Internet pharmacies" Canadian Press (17 June 2004), online: <www.mediresource.sympalico.ca/channel_health_news_delail.asp? channel_id=13 1 \&menu_item_id $=4$ \&news_id $=4247>$.

lbid.

Supra note 30.

Ibid. at 3.

Michelle Meadows, "Imported Drugs Raise Safety Concerns" (2002) 36:5 FDA Consumer Magazine, online: U.S. Food and Drug Administration <www.fda.gov/fdac/features/2002/502_import.html>. 
problem, they do not represent Internet pharmacy as a whole and are certainly not typical of Canadian cross-border pharmacies. A blanket prohibition of cross-border pharmacy is not justified by the fact that some Internet sites violate patient and consumer protection standards; any market will attract at least some dishonest operators. Despite the presence of rogue operators, in-country Internet pharmacy is sanctioned by both Canada and the U.S. as a legitimate route for filling prescriptions. Domestic Internet pharmacy represents a growing share of all pharmacy sales. Between 1999 and 2003, U.S Internet pharmacies serving American patients and purchasers increased annual sales from $\$ 160$ million to $\$ 3.2$ billion. . $^{\$-1}$ There is little reason to believe that regulators cannot effectively co-operate across the U.S.Canadian border, as they do across state and provincial borders within each country, to suppress rogue operators while encouraging legitimate business. Establishing a legal market for cross-border pharmacy, in fact, would facilitate keeping rogue operators out of the market by providing potential consumers with clearer guidance in choosing reputable pharmacies.

Cross-border pharmacies are distinguishable from problem sites because they serve different markets and have different incentives. Rogue sites market themselves as providers of discreet access to recreational and lifestyle drugs. Rogue sites sell painkillers, muscle relaxants, stimulants, "natural product" preparations, impotence treatments, hair-restorers, muscle-building supplements and the like, often advertising through unsolicited e-mail and pop-up or search engine advertising. These sites emphasize the "private" and "discreet" nature of the Internet sales transaction, relying on the dubious practice of "Internet prescribing" to assess the suitability of a drug order or even ignoring prescription requirements altogether.

In contrast, reputable Internet pharmacies are licensed by regulators in their home jurisdiction and adhere to the same level of professional service as traditional storefront pharmacies. Their business is in providing an alternative source for the widely prescribed drugs used to treat common medical conditions, stocking uncontroversial medicines and declining to sell narcotics and other abuse-prone drugs or to supply "diet aids," "performance enhancers" or other substances of dubious medical value. Valid prescriptions are always required.

As a matter of incentives, Canadian cross-border pharmacies are highly motivated to develop and maintain a reputation for safety and good customer service. Internet businesses put a high premium on gaining consumer trust, especially in the cross-border pharmacy sector, and are well aware that a failure to self-regulate will lead to loss of customers and more active, and unwanted, government intervention. ${ }^{85}$ Industry certifications like that operated by CIPA show a focus on demonstrating compliance with safety standards.

Also misleading in safety arguments against cross-border pharmacy are repeated references to "unapproved" drugs. These are inisleading because they suggest that imported drugs are necessarily substandard, but whatever the validity of this view with respect to the quality of drugs exported from some countries with weaker regulatory oversight, it cannot

*t Linda C. Fentiman, "Internet Pharmacies and the Need for a New Federalism: Protecting Consumers While Increasing Access to Prescription Drugs* (2003) 56 Rutgers L. Rev. 119 at 123. 
be seriously contended that the quality of drugs sold in Canada (or the EU) is below U.S. standards. That drugs from Canadian cross-border pharmacies are not "FDA approved" does not mean they are unsafe but only that they have been designated by the manufacturer for sale outside the U.S. These drugs are, however, approved by Health Canada (or European safety regulators). In particular, drugs sold by cross-border pharmacies are subject to manufacturing, labelling and other safety requirements that are in almost every case substantially similar, if not identical, to FDA requirements. Similarly, cross-border pharmacies are subject to provincial safety regulation that cannot be reasonably regarded as below the standard of regulation applied by state pharmacy regulators to conventional or instate Internet pharmacies. Since drug safety regulation in letter and practice is comparable in the U.S. and Canada, U.S. regulation cannot well claim that U.S. patients are not well served by Health Canada and Canadian provincial oversight of drugs they buy from Canada.

Similar continuous jurisdiction and oversight applies to shipments routed through the EU, a practice becoming more common as firms begin to regulate supplies to Canadian distributors to meet only domestic needs. On the other hand, as distribution channels become more convoluted, opportunities for error or malfeasance increase, and the FDA's admonitions about oversight become more pertinent. Continuous oversight, however, can be maintained among multiple jurisdictions with comparable regulatory capacity (European and Canadian patients, after all, regularly take drugs shipped from the U.S. and elsewhere) and the focus should be on enforcing pedigree requirements so that patients and regulators can verify that oversight has been in place throughout distribution. In cross-border pharmacy the regulatory problem is not in establishing an oversight mechanisın or gaining the co-operation of the industry; the problem is in how to prevent unlicensed sites from evading existing oversights and how to prevent foreign sites from tricking consumers into thinking they are purchasing pedigreed drugs from a pharmacy licensed in a trustworthy jurisdiction.

The appropriate standard for evaluation of cross-border pharmacy safety, particularly in terms of evaluating whether cross-border pharmacy can be adequately regulated for safety, is not whether problems can occur but rather their frequency and severity as compared to conventional pharmacy. Opponents of cross-border pharmacy have failed to show that it is more likely than sanctioned conventional or even intra-national Internet pharmacy to harm patients. The error rate for sanctioned conventional and domestic Internet pharmacy is the appropriate standard, not a hypothetical perfect distribution system. Given the millions of cross-border pharmacy sales and the dearth of reported complications, a policy of prohibition rather than regulation lacks the necessary evidential foundation.

Moreover, a rational safety analysis measures all harms, benefits and costs. The benefits of cross-border pharmacy include increased access and the provision of prescription drugs to patients who would otherwise go without, as the court in U.S. v. RxDepot found. Access must be included in calculating whether patients are better off with the option of cross-border pharmacy than without.

The safety arguments raised thus far, including more recent arguments that cross-border pharmacy would expose U.S. patients to counterfeits or even terrorist adulteration of U.S. 
drug supplies, ${ }^{86}$ in fact support the sanctioning of cross-border pharmacy, not continued attempts at suppression that are proving ineffectual against strong demand. By building supervisory capacity over cross-border pharmacy, regulators could better steer consumers towards credible and safety-compliant pharmacies. The nascent framework for imports in the current $F F D C A$ and programs defined in newer proposed legislation include a number of patient safety protections (primarily, requirements for registration of licensed distributors and provisions for the inspection of imported shipments) that would channel imports through a safe distribution network. There appear to be no particularly overwhelming barriers to the implementation of regulatory oversight of cross-border pharmacies that compel continued prohibition of imports.

\section{Canadian Regulation of Cross-Border Pharmacy}

The U.S. prohibition of prescription drug imports is only one domain of regulation to which cross-border pharmacy is subject; Canadian regulation of prescription drug sales applies as well.

\section{A. Federal Regulation}

At the federal level, Canada does not currently prohibit the re-export of prescription drugs to the U.S. Health Canada's authority over cross-border pharmacy is the same as that with conventional pharmacy: it has authority to inspect pharmacies to ensure that drugs are approved for marketing in Canada and have been manufactured, labelled and stored in compliance with federal regulations. ${ }^{87}$

While co-signing is a matter for regulation by the physician colleges in each province. the issue arises because of federal legislation. Cross-border pharmacies hire Canadian physicians to co-sign the U.S. prescriptions sent in by their customers in order to satisfy a regulation under the Canadian Food and Drugs $\mathrm{ACl}$ requiring that a Canadian physician authorize a pharmacist's dispensing of a prescription. Specifically, federal regulations dictate that prescription drugs may be dispensed by a Canadian pharmacist only by order of a "practitioner," defined as "a person authorized by the law of a province of Canada to treat patients." ${ }^{88}$ Provincial legislation in Ontario and Quebec narrows prescribing authority

Terrorism expert Alan Bell was lired by the pharmaceutical industry to present the argument that terrorists could set up fake Internet pharmacies in Canada as vectors for sending adulterated drugs in the U.S. Graeme Smith. "Was big pharma caught in its own web of spin?" The Globe and Mail (25 October 2004) A3.

*7 Food and Drugs Act, R.S.C. 1985, c. F-27. Pending legislation would apply different regulatory standards for generic drugs produced for export to developing countries. Health Canada's authority over prescription drug sales is described in Diane C. Gormaus. Assistant Deputy Minister, Health Canada. "Input from Health Canada to the Public Docket for the United States Department of Health and Human Services Task Force on Drug Importation" (3I May 2004). online: Calladian International Pharmacy Association < www.ciparx.ca/HC\%20Submission\%20tn\%20HIIS\%20Task\%20Force.pdf .

an Ibid., ss. 8-15 [empluasis added]. One Internet operation based in Ontario has taken the position that since it does not dispense to Canadian customers, it is under the law an "exporter." not a "pharmacy" and is therefore free to fill U.S. prescriptions directly, without co-signing. The business is using this argument to contest the authority of Health Canada to inspect its facitities. See "T O Internet pharmaty objects to inspections" Canadian Press (4 Marcli 2004), online: CTV <mww.ctv.ca/servleU Article News/story/CTVNews/1078407054770_4/>. As well as being a suspect interpretation of legislatise 
further, requiring that the physician be licensed in the pharmacist's province; conventional pharmacies across Canada tend to follow this practice even in the absence of a legislative requirement to do so. $^{89}$

In contrast to this Canadian requirement, 29 states permit pharmacists to recognize a Canadian prescription. ${ }^{90}$ Mexican pharmacists can also directly fill prescriptions from U.S. doctors."

Before November 2004, the federal government had not taken a position on cross-border pharmacy except to indicate that it was aware of concerns for domestic supply and was prepared to intervene (in some unspecified way) should it detect evidence of domestic shortages arising from cross-border pharmacy activity. ${ }^{92}$ In November 2004, federal Health Minister Ujjal Dosanjh took the position that because of its relatively small size, Canada could not continue to be "America's drugstore." At that time, the Minister suggested that physician Colleges should step up enforcement of provisions in their codes of ethics that forbid Canadian physicians from co-signing (or "counter-signing") U.S. prescriptions, a practice upon which cross-border pharmacies depend and which the Minister described as "immoral." In June 2005, the Minister announced he would be introducing legislation in late 2005 that would empower the government to monitor domestic drug supplies and curtail bulk exports "if there is an anticipated shortage of prescription or other needed drugs."

\section{B. College Regulation}

Subject to the (critically important) above-noted federal regulation, cross-border pharmacy services fall under the jurisdiction of the colleges of pharmacists and the colleges of physicians in each province. The colleges are self-regulating bodies that have authority to set codes of ethics and censure violating members, including by suspending or revoking a licence to practice. On appeal to the courts, college disciplinary decisions in most cases are subject to a standard of review of reasonableness; that is, a college disciplinary decision will not be overturned unless a court finds it to be patently unreasonable. ${ }^{\text {g4 }}$

language, this argunent appears counterproductive: Cannadian Internet pharmacies usually emphosize the oversight of Health Canada (and provincial pharmacy regulation) in claims to legitimacy.
Supra note 55 .

Colin Perkel, "Cross-border prescription drug trade sparks debate over Juctor ethics" Canadian Press (2 February 2004), online: Sympatico/MSN < mediresource.sympatico.ca/channel_health_new__detail asp?channel_id=|5 1 \&menu_item_id=4\&news_id=3239>.

Better Business Bureau of Southern Arizona. "Tips on Filling Prescriptions in Mexico" (10 October 2004), online: <www. tucson.bbb.org/newsrelease. html!'newsid=6\&newstype $=1>$.

Health Canada "will comtinuc to take a coordinated approach and work with all elements of the drug supply chain, such as manufacturers, distributers, wholesalers, professional associations and the medical community, as well as our provincial and lerritorial counterparts, to ensure the continued availability of safe and affordable prescription drugs for Canadians." Health Canada, News Release, "Canadla's Drug Supply"(May 2004), online: <iwww. hc-sc.ge.ca/english/media/releases/2004/internet_pharmacy
bk2.htm>. ग: Sean Gordon \& Tim Harpir. "Dosanjh sets rules for Internet drug sales" Toronto Star (30 June 2005)
A28, quoting Minister Dosanjh.

2* Pushpanahan v. Canada (Minister of Citizenship and Immigration). [1998] I S.C.R. 982. 
Cross-border pharmacies are subject to the same licensing requirements as conventional brick-and-mortar pharmacies. In Ontario, for example, Internet operations have been investigated by the College of Pharmacy for alleged violations of licensing requirements under the Regulated Health Professions Act, $1991^{95}$ and the Drug and Pharmacies Regulation Act. ${ }^{96}$

\section{Obligation to COMPLY WITH AMERICAN LAW}

Not widely noted is that cross-border pharmacy services appear to breach provisions in some provincial pharmacy codes of ethics imposing a duty to refrain from participating in a U.S. resident's violation of U.S. law. Alberta's College of Pharmacists, one of few to address this point, states:

1. Members have a tesponsibility to comply with the laws of each province, state, and country to which they provide services.

2. Present US law does not permit US citizens to import prescription drug products that are otherwise commercially available in the US. Alberta pharmacists/pharmacies should not participate in any scheme or service to accommodate such import. Pharmacies and/or pharmacists that accommodate such services may be considered to be practising unethically, and may be found guilty of professional and/or proprietary misconduct. ${ }^{97}$

Similarly, Manitoba's College holds that a pharmacy "must not contravene rules or regulations in effect in the jurisdiction where the patient resides." ${ }^{.98}$ Provincial regulations, however, limit enforcement to the reporting of a violative pharmacy to regulators in the patient's jurisdiction and U.S. regulators have little practical recourse against Canadian pharmacies. $^{.9}$

In contrast, British Columbia's College of Pharmacists has rejected the application of amity to cross-border pharmacy. In 2002, the Oregon Board of Pharmacy complained that B.C. pharmacies were dispensing prescriptions to state residents in violation of state and federal laws. The Oregon Board urged the B.C. College to instruct its members to "refrain from providing drugs and other professional services into Oregon in violation of [U.S.] and

R.S.O. 1990, c. H.4. s. $160(1)$. In 2003 inc Untario College of Pharmacists spent $\$ 500.000$ in the investigation and prosecution of The Canadian Drug Store. The consent decree included guilty pltas from the operation and its supplier and fines and seizure of inventory totalling approximately \$2\$0.(0)(1) in value. Deanne Williams. Address (Cross-border Prescribing and Internet Pharmacies Conference. 4 February 2004) |unpublished]. Alberta College of Pharmacists. "Offering Pharmacy Services via the Interne,." online: ACP Standards and Guidelines <www.pharmacisls.ab.ca/practice_ref_library/standard_guidelines.aspx"id $=2421$. The Manitoba Pharmaceutical Association. "Internet Pharmacy Standards" (2001), online: National Association of Pharmacy Regulatory Authorities < $u$ ww.napra ca/provinces/Manitoba/provincial/ internet_july0l.pdr>.

iv Letter from Ronald F. Gust. Associate Registrar of the Manitoba Pliarmaccutical Association to Jamcis T. Carder. Executive Director of the Wyoming Board of Pharmacy (4 June 2002) (on file at IIS. National Association of Boards of Pharmacy). as cited in NABP. supra note 62 al 7 
Oregon law." 100 The College's response was that "it is the responsibility of the individual [U.S.] jurisdictions to monitor for the shipment of drugs from foreign countries and for compliance by foreign pharmacies with the laws of their jurisdictions" and that it "did not support the notion that it is our College's responsibility to enforce other jurisdictions' legislated requirements." The College stated that the pharmacies known to ship drugs to the U.S. were in full compliance with all provincial laws and standards of practice. ${ }^{101}$

Other provincial colleges have also not emphasized amity as a component of professional ethics, though the National Association of Pharmacy Regulatory Authorities has pledged to work with American authorities "to promote [Canadian pharmacists'] compliance with the federal, state, and provincial laws and standards of Canada and the United States." 102

\section{CO-SIGNING}

Co-signing is the most controversial aspect of cross-border pharmacy for Canadian pharmacist and physician colleges. As mentioned, Canadian cross-border pharmacies hire local (or at least Canadian-licensed) physicians to co-sign prescriptions written by U.S. physicians in order to comply with federal and provincial dispensing restrictions. Physician colleges charge that co-signers fail to meet professional standards of care when they authorize prescription drug sales to patients they have not assessed in person. Pharmacist colleges are concerned about their complicity in behaviour the physician colleges condemn.

\section{a. Co-signing and Pharmacists}

Canadian pharmacy colleges have mostly tried to discourage members from hiring cosigning physicians, though with variable success. The B.C. college of pharmacists is somewhat of an outlier, tacitly condoning co-signing by stating that it does not consider it "the pharmacist's responsibility to determine the legitimacy of the prescribers' relationship with their patients." 103 The Manitoba Pharmaceutical Association (its "College"), as is apparent from the prevalence of cross-border pharmacies in that province, has not had much success in preventing Manitoba pharmacists from hiring co-signing physicians from across Canada, though the Association has reported a co-signing physician to his college in another province on at least one occasion. ${ }^{104}$

IIII

Letter from Gary A. Schnabel. Executive Director of the Oregon Board of Pharmacy to Linda Lytle, Registras of the College of Pharmacists of British Columbia (22 August 2002) (on file at U.S. National Association of Boards of Pharmacy), as cited in NABP, supra note 62 at 11 .

Letter from Linda Lytle, Registrar of the College of Pharmacists of British Columbia to Gary A. Schnabel, Executive Director of the Oregon Board of Pharmacy (19 September 2002) (on file at U.S., National Association of Boards of Pharmacy), as cited in NABP, ibid.

"National Association of Pharmacy Regulatory Authorities and National Association of Boards of Pharmacy Agreement" (May 2003), online: National Association of Pharmacy Regulatory Authoritics <iwww.napra.ca/pdfs/news/CrossBorderPressRelease.pdis.

College of Pharmacists of British Columbia. "Controversy swirls over international pharmacy services." (September/October 2003) 28:5 Bulletin I at 9, online: <www.bcpharmacists.org/pdf/septoct03.pdf $\mathrm{xml}=\mathrm{h}$ tup://search.atomz.com/search/pdihelper.tk?sp-0=8,100000.0>, quoting Linda Lytle, Registrar
of the College of Pharmacists of British Columbia.

The New Brunswick College of Physicians and Surgeons consequently suspended the prescribing of New Brunsirick (2003). 261 N. B (2d) 21, 2003 NBOB 
The pharmacist colleges in Alberta and Ontario have taken a more active stance. The Alberta College of Pharmacists has said:

Policies of provincial medical licensing authorities require that a physician attend and/or physically examine patients before ordering a treatment including a prescription. It may be considered unethical, unprofessional, and/or proprietary misconduct if members knowingly enter into an arrangement with a physician to prescribe medications contrary to these policies. ${ }^{105}$

The Ontario College of Pharmacists policy has declared that:

Pharmacists shall not facilitate or enter into agreements with physicians for the purposes of co-signing or rewriting prescriptions for out-of-country patients .... [P] harmacists who knowingly facilitate the practice by any Ontario prescriber to co-sign/authorize prescriptions where no established physician/patient relationship exists are acting unethically and fall below a standard of practice of our profession. ${ }^{106}$

The Canadian Pharmacists' Association (CPhA), not a regulatory body, acknowledges the benefits of Internet pharmacy but does not support co-signing:

$\mathrm{CPhA}$ recognizes that online pharmacy services from reputable pharmacies are a trend that may bertefit consumers and provide innovalive opportunities for pharmacies to serve their patients electronically. [However, w] do not support practices whereby a Canadian physician co-signs a prescription written by a physician in another country. ${ }^{107}$

\section{b. Co-signing and Physicians}

Though not a matter of regulation, it is relevant to note that the Canadian Medical Protective Association (CMPA), the professional liability insurer for Canadian physicians, will not insure for liability arising from co-signing or otherwise prescribing outside of a "prior recognized doctor-patient relationship."

Alberta's physician College holds that:

[P]rescribing medications based only on verbal information, fax, telephone or clectronic means, is not an acceptable standard of care. An appropriase histong and physical must be done first. The only exception to this policy is when physicians are fulfilling their responsibility as a member of an on-call group. As pertains to

(11) Alberta College of Pharmacists, supra nole 97.

twr. Ontario College of Pharmacists. News Release, "New Pulicy Respecting Out of Country Prescriptions Approved" Pharmacy Connection (January/February 2003), online: <www.ocpinfo.com/client/ocp/ OCPHome.nsf/web/Out+of+Country+Prescription+Policy?Open Document>.

Canadian Pharmacists Association, "FAQ's," online: <www.pharmacists.ca/content/consumer_patienV resource_centre/faqs/index.cfim\# $|S\rangle$.

tuat James Sproule. "CMPA Assistance in Internet and Cross-horder Prescribing to Non-patients: General Principles" (March 2004), online: Canadian Medical Protective Association <www.cmpa-acpm.ca portal/cmpa_docs $\% 5$ Cenglish\%5Cresource_files\%5Cinfosheets $\% 5$ Cpublic $\% 5 \mathrm{C} 2004 \% 5 \mathrm{C} 03 \% 5 \mathrm{Cpd} \%$ 5C04-internet_us_prescribing-e.pdfs. 
cross-border prescribing, therefore, signing or countersigning prescriptions written for U.S. patients by U.S. physicians may be viewed as unprofessional conduct. ${ }^{109}$

The B.C. physician College holds that:

Prescribing for a patient solely on the basis of mailed or faxed information, or an electronic questionnaire, or countersigning a prescription issucd by another physician. withou direct patien/ contact. is not an acceptable standard of medical practice.

The provision of a prescription to a patient is a medical act. It is the result of a clinical decision made by a physician subsequent to a comprehensive evaluation of the patient by that same physician. This evaluation should be based on a face-10-face encounter with the patient which includes the usual elements of clinical assessment such as the taking of a history. conducting a physical examination and any necessary imvestigations, and reaching a provisional diagnosis. Patient records should clearly reflect that the pertinent elements of the patient evaluation have been completed and documented. ${ }^{110}$

The formal position ("with which members shall comply") of the Manitoba physician college is most detailed, directing that:

Prescribing of medications by physicians based solely on information received without direct patient contact fails to meet an acceptable standard of care and is outside the bounds of professional conduct. There is no direct patient contact when the physician relies upon a mailed, fixed or an electronic medical queslionnaire or telephone advice to the physician (an exception exists for physicians who are fulfilling responsibility as part of a call group]

Counter-signing a prescription without direct patient contact fails to meel an acceplable standard of care and is outside the bounds of professional conduct.

In order to meet an acceptable standard of practice, the physician nust demonsiratc that there has been:

1. a documented patient evaluation by the Manitoba plysician signing the prescription, including history and physical examination. adcquate to establish the diagnosis for which the drug is being prescribed and identify underlying conditions and contra-indications:

2. sufficient direct dialogue between the Maniloba physician and paticut regarding treatment options and the risks and benefits of treatment;

3. a review of the course and elticacy of treatment to assess therapeutic outcome, and

College of Physicians and Surgeons of Alberta, "Prescribing On-Line" (January 2004) 107 The Messenger II, online: <iwnw.cpsa.ab.ca/publicationsresources/attachments_messengers/m I07.pdi> [emphasis added].

College of Physicians and Surgeons of British Colunibia. "Prescribing Practices, Countersigning Prescriptions and Internet Prescribing" in Physician Resource Mammal. online: <mww cpsbc.cal cps/physician_resources/publications/resource_manual> [emphasis added] 
4. maintenance of a contemporaneous medical record that is easily available to the Manitoba physician. the patient, and the patient's other health care professionals. ${ }^{11}$

The New Brunswick College of Physicians and Surgeons has not published a formal policy on co-signing, but has sanctioned at least one member for "prescribing to patients not attended $t o$ by him" upon being notified by the pharmacy college in Manitoba that he was providing co-signing services through a Manitoba cross-border pharmacy. ${ }^{112}$

These provincial colleges, then, require a "face-to-face encounter" and "physical examination," with a lone exception for prescribing in the context of on-call groups.

The Ontario College of Physicians and Surgeons also continues under an updated policy to require an "appropriate history and physical examination":

The prescribing physician needs to have a full understanding of the palient's health status. This can only be accomplished through an appropriate medical assessmemt... Generally, an assessment would include an appropriate history and physical examination, a diagnosis or diflerential diagnosis and a plan for treatment. including follow-up investigations, if indicated ... [P]rescription practices that are not acceplabale because they lack the basic elements of assessment and diagnosis include:

- Prescribing for a patient solely on the basis of mailed or faxed information, or and electronic questionnaire: [and]

- Co-signing (also called counter-signing) a prescription issued by another physician without direct patient contact. ${ }^{113}$

Exceptions to the requirement for physical examination. however, are also described:

There may be legitimate silualions where a physician can consider prescribing outside the established doctorpatient relationship. For example, physicians may prescribe:

1. In an emergency situation to protect the health or well-being of the patient:

2. In consultation with another licensed Ontario physician or another appropriate regulated health professional who has an ongoing relationship with the patient. and who has agreed io supervise the palient's treatment, including use of any prescribed medications:

3. During a telemedicine session in which the plysician has use of appropriate technology to carry out lie necessary examinations and has access to the record of the patient for whom the prescription is issued; [and]

III The College of Physicians \& Surgeons of Manitoba. "Statement No. 805 - Prescrihing Practices," online: < www.cpsm.mb.ca/aboul/by/aus_guidelines/statements/pharmacy/Statement805> [emphasis added].

112 Loiselle, supra note 104 (uphotding the College's decision to immedialtely suspend a physieian upon being notified by the Manitoba Pharmaceutical Association that he had co-signed prescriptions) at paras. 3,25 [emphasis added].

in College of Physicians and Surgeons of Ontario. "Prescribing Practices," Policy \#2-05, approved November 2001. updated February 2005, updated on website May/June 2005. online: <iwww cpso. on.ca/Policies/drug_prac.htm> 
4. During an on-call or cross-coverage situation in whicl the physician, in the exercise of his or her medical [judgment], is confident that the prescription is in the best interest of the patient. ${ }^{114}$

\section{Vil. Evaluating Canadian Regulation}

Pharmacist and physician college rationales for characterizing co-signing as per se unethical are not immune to critique. Ethical codes should reflect the best interests of the patient, and by this standard the justification for a blanket prohibition on co-signing is suspect.

As a general matter, college statements appear to equate the practice of co-signing with "Internet prescribing," a practice wherein a Web-based questionnaire or text conversation takes the place of a visit to a doctor. Regulator statements on each practice emphasize the necessity for an in-person assessment or at least a "relationship" between patient and physician. Intemet prescribing, however, is not equivalent to co-signing and has wholly different implications for patient safety. The prohibition on prescribing without an in-person medical assessment is founded on the need for a medical professional to act as gatekeeper and supervise patient use of potentially harmful or unnecessary prescription drugs.

The in-person assessment rule was developed by physician regulators (initially, primarily in the U.S.) as a response to Web sites that arose selling narcotics and other clearly dangerous, highly restricted drugs without a pre-existing prescription. These sites misused "Internet prescribing" as a sham to avoid the purpose of approving some drugs for sale only by prescription. "'s Given the practical difficulty of distinguishing sites practising Internet prescribing in good faith, where a physician actually reviews a prescription request, from sites where Internet prescribing is a sham, the policy most widely chosen by physician regulators was to prohibit Internet prescribing.

Unfortunately, policies requiring a "direct," "physical" and "in-person" meeting between patient and physician, while arguably justifiable in the face a proliferation of rogue Internet businesses peddling narcotics without a prescription, do not fit the circumstances of crossborder pharmacy sales to seniors seeking refills of cholesterol medication. The root concern is that a physician has and uses all the information relevant to a well-founded decision to prescribe a drug. While requiring an in-person assessment curtails sham Internet prescribing, it is not at all clear that a physician acting in good faith cannot obtain the necessary information to make a prescribing decision, or perform other medical acts, remotely from the patient. That is, the in-person assessment rule is a means, not an end: the end is meaningful physician oversight of a patient's prescription drug use. Assessments not requiring palpitation of the patient, for example, could be conducted by teleconference, or, where direct observation of the patient is not necessary, even by telephone or Internet. Even where a blood test or other physical assay is required, a technician could perform the necessary in-person portion of the exam and the physician could remain at a remote location. This, in essence, is the nature of telemedicine, a legitimate form of the practice of medicine. Standards of 
practice in telemedicine explicitly recognize that patient safety concerns can be satisfied through the remote provision of all the information a physician requires. ${ }^{116}$ Professional regulator emphasis on the need for in-person assessments is therefore unpersuasive as an absolute rule for physician conduct.

In any case, a patient-centered perspective reveals that Internet prescribing and co-signing are entirely difference circumstances. Most significantly, in co-signing there is a conventional, in-person assessment by the U.S. physician who sees the American patient and issues the prescription. The repeated emphasis and condemnation by Canadian physician colleges of Canadian physicians' prescribing to unassessed patients completely mischaracterizes the logistics of cross-border pharmacy and grossly overstates risk to the patient. ${ }^{17}$ In cross-border pharmacy, the patient's use of a drug is vetted by two physicians, one of whom conducts a conventional in-person assessment while the other does so remotely through a review of the patient's medical history. There is little reason to suppose that American patients are put at greater risk from the additional oversight of a Canadian cosigning physician than they would were their prescriptions being filled on the basis of the U.S. physician's prescription alone. Co-signing increases the risk to patient safety only when the co-signing physician errs in transcribing or translating the prescription (for example, into drug trade names used in Canada but not the U.S.), but in no case represents a situation where the patient is not assessed in the conventional manner. Further, against the rate of introduced error must be measured the rate of correction by co-signing physicians of errors committed by the U.S. physician - these together provide a more accurate and useful picture of the impact of co-signing on patient safety.

Co-signing physicians dispute the charge that they are "in no position to assess the appropriateness of the prescription." 118 Most obviously, it cannot be seriously argued that U.S. physicians are any less qualified than Canadian physicians or that U.S. prescriptions are likely to be inappropriate. Furthermore, cross-border prescriptions are accompanied by a medical history and list of concurrent medications. The major cross-border pharmacies report that they commit significant resources and effort to ensuring that prescriptions are appropriate, and have in fact caught a number of prescribing errors committed by U.S. physicians. ${ }^{119}$ The Canadian physician is authorized by the patient to contact the American physician in case of questions or concerns. Finally. most co-signing is for refills of

116 National Initiative for Telehtealth (NIFTE), Framework of Guidelines (September 2003), online: Canadian Society for Telehealth <www.cst-sct.org/resources/Frameworko/Guidelines2003 eng.pdf>. See also American Telemedicine Association, Telemedicine Guidelines and Technical Standards Affecting Telemedical Transmissions, online: <www.atmeda.org/news/newres.htm>

The confusion of the rationales for prohibiting Internet prescribing and for prohibiting cross-border pharmacy is evident in Florida governor Jeb Bush's explanation of his state's recent move to close down storefront operations, when lie said: "We're not going to allow for storefront pharmacies that have no contact between a doctor and a patient to be able to sell prescription drugs to Floridians because of safety concerns." CanWest News Service and Canadian Press, "Trade's great. Jeb says - except in drugs, Irains" Edmonton Journal (30 July 2004) $A 7$. htm>. 
medications patients have been taking for some time, where concerns about the appropriateness of a prescription are greatly diminished.

The colleges' statements on co-signing also reflect a false emphasis on physicians as isolated experts. Physicians, however, do not breach legal or reasonable professional standards of care only by virtue of their reliance on a patient assessment performed by another physician. ${ }^{120}$ In fact, under other circumstances the colleges endorse prescribing by physicians who have not themselves seen the patient. The Alberta and B.C. colleges, for example, make an exception to the requirement that the prescribing doctor have personally attended the patient for doctors who are part of an on-call or group practice. ${ }^{12}$ Saskatchewan goes further and supports prescribing to an unseen patient when done "in consultation with another Saskatchewan physician who has an ongoing relationship with the patient, and who has agreed to supervise the patient's treatment, including use of any prescribed medications." 122 This, of course, is the situation with co-signing, except that the other physician (and patient) is in the U.S. Since the colleges endorse prescribing to patients not seen directly by the prescriber as long as another physician has seen and continues to see the patient, co-signing cannot be per se below a reasonable standard of care.

The appropriate policy is the one that promotes maximal patient benefit and minimizes the potential for patient harm. Re-orienting professional college policy towards the development of "good practice" standards would be better policy than outright prohibition of co-signing: it would more accurately reflect the relatively low likelihood of harm introduced by the cosigning element of cross-border dispensing, and, in light of the fact that some patients would go without medication but for cross-border pharmacy, it would be the more beneficent approach. Sanctioning and effectively supervising cross-border pharmacy would also better respect patient autonomy, a principle overlooked in prohibitory policy statements.

While Canadian colleges are consistent in publicly declaiming co-signing, enforcing prohibitions on cross-border pharmacy is a responsibility under which some regulators are beginning to chafe. The issue is divisive among members and even some strong opponents to cross-border pharmacy have questioned whether it is an appropriate use of Canadian resources to enforce a policy that ostensibly protects American patients. ${ }^{123}$

121 National Association of Pharmacy Regulatory Authorities, "Prescribing lor U.S. Patients" (Jantary 2003), online: <iwww.napra.ca/pdis/practice/0301 12Prescribing\%20lor\%20US\%20patients.pdi> The College of Physicians and Surgeons of Saskatchewan. "Bylaws Pursuant to The Medical Profession ACt, 1981," online: <winv.quadrant.net/cpss/pdf/CPSS_Bylaws.pdf>.

12

Williams, supra note 96. As an example of the expense involved, in 2003 the Ontario College of Pharmacists spent in excess of $\$ 500,000$ to investigate and prosecute an Internet operation carrying itself off as a Canadian cross-border pharmacy. The case was settled in the Ontario Court of Justice in June 2003 after The Canadian Drug Store pled guilty to contravening the Regulated Health Professions Act. 1991, supra note 95 and the Drug and Pharmacies Regulation Act, supra note 96, ss. 139(1), $142(1), 149(1), 155(1)$ by practicing pharmacy without a licence. The wholesale supplier pled guilty to the offence of wholesaling drugs "for the purpose of sale by retail to any person who is not entitled to sell the drug by retail" (Drug and Pharmacies Regulation ACt, supra note 96, s. 16011)). The Canadian Drug Store was fined $\$ 20,000$, an amount that took into account the loss of $\$ 155,000$ in product seized by the College and the company's agreement to give $\$ 150,000$ to the Leslie Dan Faculty of Pharmacy at the University of Toronto for a professorship. Ontario College of Pharmacists, News Release, "The Canadian Drug Store Inc. Pleads Guilty" (17 July 2003). online: <www.ocpinfo.com/ 
The physician colleges could avoid the co-signing issue if federal and provincial legislation were amended to allow Canadian pharmacists to fill U.S. prescriptions directly. That 29 U.S. states allow their pharmacists to fill Canadian prescriptions suggests this would not be an innately unreasonable approach. A potential objection is that the purpose of designating drugs to prescription status (i.e. having a physician evaluate the appropriateness of a drug treatment with potential side effects) would be undermined in U.S. states that allow naturopaths and other non-M.D.s to write prescriptions. This argument, though, is not compelling. Canadian pharmacists could be authorized to accept such prescriptions on the theory that a U.S. patient's home jurisdiction is the appropriate forum for setting the qualifications of prescribers; altematively, Canadian pharmacists could be authorized only to fill prescriptions written by medical doctors.

\section{Emergent Frameworks: Intel.lectual. Property, COMPETITION LAW AND ECONOMICS}

Patient safety has been the primary framework for discourse in assessing the legitimacy of cross-border pharmacy. Other frameworks of analysis, however, are relevant as well: intellectual property law, competition law and economics.

\section{A. Intellectual. Property}

Some analysts have argued that cross-border pharmacy infringes U.S. patent rights to exclude others from selling or importing drugs in the country that issued the patent. ${ }^{124}$ It is not controversial that drug firm patents would be infringed if cross-border drugs were manufactured without patent authority or as generics in Canada, for example if a drug's patent protection in Canada expired before the U.S. patent. Such cases, however. are extremely rare. ${ }^{12 s}$ Rather, the drugs sold by cross-border pharmacy are almost invariably manufactured under authority of the patent holder and sold by authorized channels to Canadian or other overseas distributors who in turn supply cross-border pharmacies. ${ }^{126}$ Should Canadian pharmacies' subsequent retail sales to U.S. consumers constitute infringement?

At issue is the scope of the common law principle of exhaustion (the "first sale doctrine"). Under this principle of patent law, an authorized sale by the patent holder (or licensee) of a patented item "exhausts" the patent holder's right to exclude others from re-selling that particular item. This principle ordinarily allows a buyer of a patented good to re-sell that

clienUoep/OCPI lome.nsi/web/News+Release+July+17+2003?Open Documen1>.

12. John R. Graham, "Prescription Drug Prices in Canada and the United Stales-Part 4: Cantadian Prescriptions for American Patients Are Not the Solution" (2003) 70) Public Policy Sources 1 at 15. Wendy Wagner, "Patent Rights and Cross-border Pharmacy." Symposium: Cross-Border Internet Pharmacy - Public Policy Implications. supra note 31

123 Wagner, ibid.

12" Some cross-border pharmacies call their drugs "Canadian generics," hut this is almost always incorrect because patent terms are usually the same on both sides of the border. 
good without authorization from the patent holder without committing infringement. ${ }^{127}$ This is why there are legal markets in used patented goods.

The controversy over the application of exhaustion arises when the first sale occurs in a different patent jurisdiction from that of the second or subsequent sale. It is settled U.S. law that exhaustion applies when the first authorized sale from the patent holder takes place in the jurisdiction that issued the patent: patented goods obtained with authorization in one state may be freely sold in another. Unsettled, however, is whether U.S. patent rights are exhausted "internationally," or when the first sale of a good patented in the U.S. occurs outside the U.S. ${ }^{128}$ If patent rights exhaust internationally, then retail sales into the U.S. of drugs originally sold under the authorization of the patent holder anywhere in the world would not constitute infringement.

In Europe, patent rights are deemed to exhaust "regionally" and therefore do not present a barrier to parallel trade in pharmaceuticals. Proposed U.S. legislation authorizing drug imports would deem pharmaceutical patent rights exhausted internationally. ${ }^{129}$ The WTO's Agreement on Trade-Regulated Aspects of Intellectual Property Rights allows signatories to address the issue of exhaustion as they wish. ${ }^{130}$

Most analyses of whether U.S. patent rights should exhaust internationally adopt a law and economics approach, assessing potential effects on the marketplace and innovation and the costs and benefits of differential pricing. Differential pricing is a seller's strategy of setting different prices for separate consumer groups according to their willingness and ability to purchase the good. In theory, differential pricing maximizes the seller's profit allowing him to charge higher prices to those willing to pay them and minimizing the share of the market lost by too-high prices, while consumer welfare is maximized because fewer people are priced out by wealthier consumers. A number of analysts argue that international price differentiation should be supported by an intellectual property regime in which patent rights exhaust nationally, not internationally. ${ }^{131}$

It is important to note that a right to re-sell resulting from the operation of the principle of exhaustion is separate from a right or restriction to re-sell created under contract. An authorized buyer may be restricted in their freedom to re-sell under a purchase agreement made with the patent holder. Such restrictions are now included in sales contracts between U.S. patent holders and major Canadian wholesalers.

Jazz Photo Corporation v. Imternational Trade Comm 'n, 264 F.3d 1094 (Cir. 2001), cert. denied, 122 536 U.S. 950 (S.C. 2002).

:B: Fentiman, supra note 84.

1.2 WTO, Agreement on Trade-Related Aspects of Intellectual Property Rights, being Annex IC to the Agreement Establishing the World Trade Organization, ant 6 [TRIPs], online: WTO <www, whto.org/ english/docs_e/legal_e/27-trips.pdfs.

(11 See e.g. Patricia M. Danzon, "The Economics of Parallel Trade"(1998) 13:3 PharmacoEconomics 293; Patricia M. Danzon \& Adrian Towse, "Diflerential Pricing for Pharmaceuticals: Reconciling Access. R\&D and Patents" (2003) 3 International Journal of Health Care Finance \& Economics 183; Claude E. Barfield \& Mark A. Groombridge, "Parallel Trade in the Pharmaceutical Industry: Implications for Innovation. Consumer Welfare, and Health Policy" (1999) 10 Fordhain Intell. Prop. Media \& Ent. L.J. 185 at 190-99: Carsten Fink. "Entering the Jungle: The J:xhaustion of Intellectual Propeny Rights and Parallel Imports" in Owen Lippert. ed., Competitive Sirategies for the Protection of Intellectual Property (Vancouver: Fraser Institute, 1999) 173; Wanwick A. Rothnie. Parallel Imports (London: Sweet \& Maxwell, 1993) at 170-85. 
Even assuming for the moment that differential pricing of prescription drugs is a preferred economic policy for Canada and the U.S. to pursue, however, there remains the question of whether patent law is the best instrument to use to that end.

The function of patents is to protect innovators from the free-riding of imitators who do not bear research and development costs. ${ }^{132}$ They did not originate or develop as a way for sellers to protect their ability to practice differential pricing to customer groups. The legal and policy goals of patent law, and the competing interests it must balance, differ from those on which international trade has focused. Although differential pricing policy shares with patent law a concern for protecting the profit incentive to innovate, this does not mean patent law is the best instrument for supporting differential pricing. Indeed, a number of bodies of law besides patent law impact on drug firm profitability and hence on their incentive to innovate.

The issues and competing interests relevant to cross-border differential pricing would appear to be better suited to regulation through international trade than patent law, and the institutions of international trade better suited than patent courts to mediating disputes. In fact, international trade agreements explicitly preventing drug buyers in low-price nations from exporting to high-price nations have been negotiated between the U.S. and several countries, including Australia. Trade agreements allow precise regulation of cross-border drug flows, obviating the need to establish a principle of national patent exhaustion which could have unpredictable consequences for other industrial sectors (for example, where U.S. firms take advantage of cross-border arbitrage to lower production input costs) and for patent law more generally.

Trade agreements can be thought of as elevating to a national level the contract provisions and legislation that have long been used to restrict arbitrage between drug markets, both within the U.S. and more recently internationally, without reliance on patent law. For example, the U.S. Veteran's Administration pays discounted drug prices roughly on par with Canadian retail prices, but is not authorized to re-sell those drugs at a profit. Discount programs for low-income seniors, offered directly by firms, may only be used for the program member's personal needs. Most recently, firms have restricted Canadian wholesalers from supplying "blacklisted" dealers who supply the cross-border trade and limited sales volumes to projected domestic demand. Admittedly, a disadvantage of such contracts is that they are enforceable only against the contracting parties, complicating firms' ability to intercept drugs that go outside authorized distribution channels. Patent rights, which apply against any person, appear to offer an advantage in this regard. A trade agreement, however. also elevates the enforcement powers of firms to prevent unauthorized cross-border sales by any person.

It has been argued elsewhere that Canadian buyers free-ride on American buyers by contributing less to R\&D costs, but by the same token the cost of doing business (advertising. liability) in the Canadian market is lower as well, so the price difference between Canada and the U.S. need not represent a difference in contribution to researcli and development. Moreover, it could equally be argued that large U.S. buyers who negotiate discounts from retail prices or benefit from price regulation, like the Veteran's Administration. are free-riding on buyers who pay the highest prices: uninsured American seniors. 


\section{B. Competition LaW}

Competition law touches on cross-border pharmacy in that firms now routinely restrict Canadian distributors from supplying cross-border pharmacies. The North American Free Trade Agreement (NAFTA) allows countries to grant patent holders the general right to attach terms and conditions to the sale of their goods that restrict re-sale across national borders. ${ }^{133}$ Domestic competition law in the U.S. and Canada, however, scrutinize resale restrictions to ensure they are not "anticompetitive." Anticompetitive behaviour can lead to both civil and criminal remedies. Pro-import U.S. states are exploring whether manufacturers who restrict sales to Canada violate U.S. competition law. Minnesota's Attorney General, for example, is investigating whether drug firms are conspiring to maintain retail prices in the U.S. in restricting Canadian sales volumes and blacklisting cross-border distributors. Twentyfive states have signed on to supportive briefs. ${ }^{134}$ Illinois is pursuing a similar investigation. ${ }^{35}$

In both Canada and the U.S., contractual re-sale restrictions are evaluated under competition law on a case-by-case basis using a "rule of reason" standard. Under this standard, re-sale restrictions are permitted when they produce a net economic efficiency gain to society. ${ }^{136}$ The rule of reason test generally entails inquiring "whether the restraint is likely to have anticompetitive effects and, if so, whether the restraint is reasonably necessary to achieve procompetitive benefits that outweigh those anticompetitive effects." 137 Re-sale restrictions are also permitted when they serve a "legitimate business purpose."

In early 2003, a group of Canadian cross-border pharmacies filed a complaint with the Canadian Competition Bureau alleging that GlaxoSmithKline (GSK) had acted anticompetitively in refusing to supply the pharmacies' distributors. The Bureau did not undertake the more complex analysis required for determining whether an impugned restriction has a net procompetitive effect but rather disposed of the complaint by finding there was a "legitimate business purpose" to the restrictions because drug imports are prohibited under U.S. law. Importantly, the Bureau did note, however, that resale restrictions

III Rothnie, supra note 131 at $170-85$

1.4. "GlaxoSmithKline ordered to give Minnesota info on limiting drugs to Canada" (1I May 2004) Canadian Press, online: <www.medbroadcast.com/health_news_details.asp?news_channel_id=1000\& news_id $=4049$ >.

115 A matter arising in another industry may yield guidance on how competition law applies to cross-border distribution restrictions. A class action suit has been brought against U.S. auto manufacturers by car dealerships that sought to import new cars from dealers in Canada but were prevented from doing so by manufacturer re-sale restrictions imposed on Canadian dealers. Manufacturers also voided car warranties on Canadian cars bought by U.S. consumers. The plaintiffs claim these restrictions are an unlawful conspiracy to reduce competition. See Berman DeValerio Pease Tabacco Burn \& Pucillo, "Canadian Car Antitrust" (19 February 2003), online: <www.bermanesq.com/Antitrusu/CasePage. asp?caseid $=464>$. discrimination" (1994) 37 Journal of International Economics 167 at 168; Andrew Ruff, "Relcasing the Grays: in Support of Legalizing Parallel Imports" (1992) II UCLA Pac. Basin L.J. I 19. 
that adversely affected Canadian domestic supplies would be outside the scope of the legitimate business purpose exception. ${ }^{138}$

This decision suggests that Canadian competition law regulators will not interfere with resale restrictions as long as U.S. prohibitions on drug imports remain in effect. In fact, a recent European decision suggests that firms may be able to argue they have a "legitimate business purpose" for otherwise anticompetitive re-sale restrictions even if the U.S. import prohibitions were no longer in effect. During proceedings brought by competition authorities in Europe, where cross-border pharmacy imports are not nationally prohibited as they are in the U.S., the Advocate General to the European Court of Justice (ECJ) submitted a legal opinion that re-sale restrictions in the absence of import restrictions "should not be considered abusive where the differences in prices of medicines between the Member States are the result of State intervention [price regulation, as in Canada] and in the light of the specific circumstances of the European pharmaceutical market," so long as the pharmaceutical manufacturer is providing enough product to meet the buyer country's legitimate needs. ${ }^{139}$ In May 2005, the ECJ declined to address the case on its merits, finding the Competition Commission in Greece lacked standing to refer the matter to the Court. Left standing was the Competition Commission's finding that GSK's refusal to supply wholesalers who were supplying parallel trade markets was an anticompetitive act. ${ }^{140}$

It remains to be seen whether competition law provides any assistance to proponents of cross-border pharmacy or whether the legitimate business purpose will instead permit firms to impose re-sale restrictions on distributors in order to close off cross-border supplies, even if imports become sanctioned under the current $F F D C A$ or new legislation. Encouragingly for Canadians concerned about potential adverse effects of cross-border pharmacy (or more precisely, firm reactions to cross-border pharmacy) on domestic supplies, both the Canadian and European decisions suggest that competition authorities will not tolerate resale restrictions that are so restrictive as to threaten domestic drug supplies.

\section{ECONOMICS}

The basic economic argument against cross-border pharmacy is that it will lower firm profits and reduce the rate of innovation of new drugs, but this argument makes a number of factual and normative assumptions worth examining. ${ }^{\text {ISI }}$

Industry Canada, Competition Bureau of Canada, Media Release. "Competition Bureau Responds to Complaints Regarding Supply of Canadian-Based Internet Pharmacies" (21 March 2003), online: Strategis <wmw. strategis.ic.gc.ca>.

Coun of Justice of the European Communites, Press Release, No. 87/04. "Refusal by a Dominant Pharmaceutical Undertaking to Meet All Orders of its Customers so as to Restrict Parallel Trade Does Not Automatically Constitute an Abuse of a Domninant Position" (28 October 2004). online: <www. curia.eu.int/en/actu/communiques/cp(24/aft/cp040087en.pdi>. See also "Hot Topic: Parallel trade market integration or free riding?" (27 May 2005), online: Linklaters < www.linklaters con/uews anddeals/newsdetail asp? newsid $=2340$ \& navigationid $=205>$.

European Association of Euro-Pharmaceutical Companies. Press Release. "Furopean Court's decisıon incans Glaxo must mect supply orders in full in Greces" (3I May 2005). online: Europuin Association of Euro-Pharmaceutical Companies <iwww.caepc.org/news_and_press/press_releases.php?n=3\&id $\Rightarrow 246>$

is! Donald W. Light \& Joel Lexchin. "Will Lower Drug Prices Jeopardize Drug Researeh? A Policy Fact Sheet" 4:I American Journal of Bioethics 1. 
A point to consider is the efficiency of the pharmaceutical industry's production of innovation. In paying higher prices now to support future innovation, are consumers getting a good deal? To what degree can firms be relied upon to deliver the improvements to health care for future patients that are used to justify reduced access for current patients? In the abstract, some trade-off is clearly necessary - the patent system is founded on the idea that temporarily higher prices are needed to induce the very creation of new products. This is the "dynamic efficiency" of patents. But the answer to how much higher a price to pay and how much access to forego depends at least in part on how beneficial the new products will be.

From this perspective, drug price regulation based on cost-benefit assessment, as Canada and other OECD countries apply, offers advantages over the advertising-driven consumer choice model characteristic of the U.S. Price regulation not only smoothes out distributional inequities that arise under free market pricing when there is a significant gap in the purchasing power of the rich and poor, as in the U.S., but also helps remedy the consumer's necessarily imperfect information about the value of a prescription drugs. ${ }^{142}$ Tying price and firm profit opportunities to objective measures of value also creates incentives for firms to direct innovation in more socially useful directions than is the case where firms have the power to create markets for drugs that provide more profit opportunity than medical value. In leaving drug prices to market forces alone, the U.S. is an outlier among OECD nations in not systematically using cost-benefit analyses. ${ }^{143}$

The argument that reduced profit leads to reduced innovation, a testable hypothesis, in any case begs more fundamental normative questions about profit, prices and drug development. Is innovation the only, or ultimate, value and purpose of the economic system of drug development and distribution?

\section{The Value of access}

Innovation is important but not an overriding goal. Most importantly to cross-border pharmacy, innovation is in tension with the goal of access. In fact, it can be argued that access is the more fundamental goal since innovation is valued precisely because it promises improved access and care for future consumers/patients. The high prices firms pursue in maximizing profit and that are justified as necessary to enable further innovation also reduce present access; government's role is to mediate the balance between access and innovation. ${ }^{14}$

A number of clinicians, researchers, economists, and other analysts argue that the purchasing public gets a very poor return on its investment in privately liunded innovation from drug companies. in no small part because, in the pursuit of profit, firms push against. and sometimes transgress. the boundaries of scientific. legal and ethical legitimacy. For recent examples, sec Marcia Angell. The Truth About the Drug Companies: How They Deceive Us and What to Do Abour /h (New York: Random House. 2004): Merrill Goozner, The \$800 Million Pill: The Truh Behind the Cest of New Drugs (Berkeley: University of California Press, 2004): David Healy, Let Them Fat Prozac: The Unhealliny Relationship Between the Pharmaceurical Industry and Depression (New York: New York University Press. 2004).

i'I Jay M. Canter, quoted in Elisabeth Pena, "Managing Outcomes" (2004) 4:7 Pharmal Voice I at 4

11. For a case study of how two countries sought to balance goverument's dual and sometimes conflicting roles as "economic maximizer" and "social provider" in the realm of patent policy for pharmaceuticals, see Jillian Clare Cohen. "Canada and Brazil - Dealing with Tension between Ensuring Access to Medicines and Complying with Pharmaccutical Patent Standards: Is the Story the Same?" Comparative 
If high drug prices and the widespread lack of insurance conspire to create an access problem, then either lowering prices or providing more widespread insurance, or both, are potential responses. Firms would clearly prefer that governments address access problems though insurance. All OECD countries try to provide public coverage programs for the very poor or those with catastrophic drug costs in order to minimize the number of people forced to choose between medicine and other essentials. Some countries go further and provide universal coverage through more or less public systems. Public insurance, though, must compete with other social programs for limited public funds. All public coverage programs use formularies and other price-constraining measures to limit costs. ${ }^{145}$ All cost-constraining measures limit the profit potential of private firms. Any reduction in profits resulting from cross-border pharmacy is fundamentally not different in kind from other methods governments use to promote access.

Though some public programs in the U.S. (for example, the Veterans Administration) employ price controls, these are not available for the Medicare drug coverage program established in December 2003 by the Medicare Prescription Drug. Improvement, and Modernization Act of 2003. ${ }^{146}$ "Non-interference" provisions disallow federal and state governments from setting prices, mandating formularies or participating in negotiations among manufacturers, plan administrators and pharmacies. ${ }^{147}$ These restrictions on government's ability to constrain costs through price constraints (based on legislative or monopsony power) have contributed to doubts about the viability of Medicare drug coverage over the long term since firms have historically tended to raise prices despite cost constraints. ${ }^{148} \mathrm{U}$.S. drug prices have followed a long-term upward trend, increasing by 3.4 percent (three times the rate of inflation) in the six months following the passage of the Medicare Improvement $A C l$, after having risen by 6.9 percent (six times the rate of inflation)

Program on Health and Society Working Paper Series 2003/2004. online: University of Toronto $<w w w . u t o r o n t o . c a / c p h s / W O R K I N G P A P E R S / C P H S 2003$ Jillian_Cohen.pdf>. Jacobzone, supra note 6 at 27.

Pub. L. No. 108-173, 117 Stat. 2066. Full text and more information is available online at Medicare Modernization Update <www.cms. lhhs.gov/mınu/LRI/HR J.pdf> (last modified: 13 AugusI 2004).

For a critique of the restriction on direct government negotiation with manufacturers. see Terri Shaw. "Prescription Drug Prices: Harnessing Medicare's Purchasing Power" (27 January 2004) Center for American Progress, Medicare Policy Brief \#I, online: <www.americanprogress.org/AccountTemp Files/cf/ $\{$ E9245FE4-9A2B-43C7-A521-5D6FF21:06E(13//mma.pdP. For a defence. see U.S. Centers for Medicare \& Medicaid Services, Departinent of Health and Human Services, "Medicare Drug Benefit Uses Price Negotiation to Get Best Possible Drug Prices" Issue Paper \# 10 (19 Janury 2005), online: <www.cms.hhs.gov/medicarereform/issuepapers/titlel and2/files/issue_paper_10_-_price_negotiation_ to_lower_drug_prices.pd $>$. and United States Senate Republican Policy Committee "Competition vs. Price Controls: The Road to Lower Prescription Drug Prices" (9 March 2004). online: <http://kyl.senate.gov/legis_centcr/rpc/030904.pdf>. Non-interference provisions have been defended as promoting the incentive for firms to innovate drugs more likely to be used by low-income seniors. Sce also Christopher Sean Jackson. "Incentives and Innovation: Pharmaceutical Research and L.owIncome Groups under the Proposed Medicare Prescription Drug Benefit" (2003) 5 N.C. J.L. \& Tecls. 81.

Prices have been raised despite legal restraints. Schering-Plough, for example. pled guilty to a number of fraud clarges and pid a $\$ 345$ million settlement in July 2004, andmitting it had used secret paybanclis and other means to inthate the apparent "best price" obtained by non-government buyers; several statcs mandate their Medicaid programs pay no more than a percentage of the private sector "best price." Reved Abelson, "Schering Case Demonstrates Manipulation Of Drug Prices" The New Fork Times (31 Jul! 2004) Cl. 
in the year prior. ${ }^{149}$ In the absence of downward price pressure from cross-border pharmacy, there is concern that rising drug prices in combination with an aging population will eventually force limits in coverage and erode hoped-for improvements in access. Estimates of the cost of the program over ten years increased from $\$ 4$ billion to $\$ 5.5$ billion within weeks of the $A C t$ 's passage. ${ }^{150}$

Canada has been much more successful in containing price increases than the U.S. After the inception of the PMPRB in 1987, median Canadian prices declined from 23 percent higher than the median of prices in seven comparator countries to 5-12 percent below the international median in 1994. Relative Canadian prices then increased to about 1 percent above the international median in 2001, where they have since stabilized. Since 2001, average drug prices of patented medicines in Canada and the comparator countries outside the U.S have risen at an annual rate of about 1 percent. In the U.S, average drug prices have increased by 5 percent per annum and in 2002 were 67 percent above average Canadian prices. ${ }^{\text {Is! }}$

By exposing the U.S. market to Canadian prices, then, cross-border plarmacy serves as an important check on the tendency of U.S. prices to increase more rapidly than elsewhere. Cross-border pharmacy has already induced firms to offer discounts to low-income, uninsured patients. ${ }^{152} \mathrm{Pfizer}$, for example, hopes to reduce demand for cross-border pharmacy (or at least undermine the argument that cross-border pharmacy is necessary) by offering some of its drugs for free to very-low-income patients and at an average 37 percent discount for low-income patients. ${ }^{133}$ Thus far, firm-sponsored discount programs like this have been criticized as unwieldy and inadequate, requiring extensive and repeated applications from prescribing physicians and applying only to some drugs. Most significantly, these programs do not result in the price discount (30-80 percent) to be had from re-imports.

Because the public purse is limited, then, the expansion of publicly funded insurance, advocated by firms as an alternative to regulating lower prices, does not resolve the tension between the interest in investing in future innovation and the interest in "cashing in" on past investment in innovation by providing access to today's patients. Adoption by taxpayers of

14\% "Group: Drug costs up after Medicire discounts started" Reurers (1 July 2004), online: Health All News <www.allhealthnews. Inel/news. Ittul?vicw $=8674$ >.

14. Amy Goldstein. "Olficial Says He Was Told to Willhold Medicare Data" Washingron Post (13 March 2004) Al, online: washingtonpost com < www. washingtonpost.com/ac $2 / w p$-dyn?pagename tarticle\& node=\&contentld=A54524-2004Mar 12 \&notFound=true $>$. See also U.S. Congressional Budget Ofice, "A Detailed Description of CBO's Cost Estimate for the Medicare Prescription Drug Benedit" (July 2004), online: <www.cho. gov/showdoc.cfm?inde $x=5668$ \& sequence $+1>$.

is! Treasury Board of Canada Secretariat. Patented Medicine Prices Review Board Canada, "Performance Report for the period ending March 31. 2003." online: <www.tbs-sct.gc.ca/rma/dpr/02-03/PMPRBCEPMB/PMPRB-CEPMB03D01_e.asp\# $21>$ at Figures 3 \& 4.

13: The Cost Containment Researcl Instilute in Washington, D.C. publisles a booklet of mantulicturer programs, listing roughly 1.100 medications made by 95 manulacturers with assistance programs. Information on manufteturer programs can also be found at Partuership for Prescription Assistance. online: <mww.pparx.org/ntro.php>: and at Frec Medicine Program, online: <muw. freemedicine program.coms. See Patricia Sabatini, "Programs Make Low-Cost Drugs Available At Home" Piltsburgh Post-Gazelle (23 July 2004) Cll. 
the cost of drugs for universal and comprehensive coverage at the prices firms now charge in the retail market is simply not possible. Even the more limited coverage provided by Medicare may not be sustainable in the absence of the price constraints imposed (directly or indirectly) by cross-border pharmacy.

\section{The VALUE of INNOVATION}

It is inevitable that the special value of health will inform the political process of finding a balance between investment in innovation through higher drug prices and improvement of access through lower user prices. Personal interest in good health differs significantly from the satisfaction of desires for more, better and cheaper ordinary consumer goods. Economics can sensibly quantify the enabling value of health in terms of productivity, but as a mode of analysis it deals less adequately with certain fundamentals related to health: dignity, wellbeing, even life. Economics can assist in formulating policies that further chosen values, but is less well equipped for addressing which values should govern. Good health enables the achievement of everything else that is meaningful to people, even while these things resist ready quantification under economic analysis and are therefore susceptible to being undervalued or ignored in an economic framework. Because economic discourse is so influential, even dominant, it is important that the social and moral worth of health remain at the fore of law and policy analysis. Indeed, under international human rights instruments and the most progressive post-Weimar era Constitutions, access to health care is explicitly recognized as a legal right circumscribed only by the capacity of the state to provide that access. ${ }^{154}$ The special status of health as an enabling or rights-like good justifies government intervention in drug markets to promote access and avoid distributional injustice.

That said, the special value of health does by itself indicate whether to favour one over the other because both access and innovation are routes to health, only for different patients: present and future. Taking the long view, it is difficult to argue on moral grounds alone that current patients who need health through access (lower prices) have a stronger claim than future patients (or present patients in the future) who need health through innovation (higher prices). More helpful is to consider to what degree the loss of potential access, through high prices, is compensated for by the production of clinically useful innovation for the future. The special value of health, in other words, not only raises the issue of access but presses the point that the appropriate question is how effectively pharmaceutical policy yields innovation (and more precisely, clinically useful innovation) in proportion to health sacrificed due to higher prices. A beneficial side effect of the debate over cross-border pharmacy may be to draw attention to the ways countries can create incentives for firms to focus on socially beneficial, rather than merely marketable, new drugs.

See. e.g. Constintion of the World Health Organizalion. as adopted by the International Health Conference, 22 July 1946; Universal Declaration of Human Rights. GA Res. 217 (III). UN GAOR. 3d Sess.. Supp. No. 13. UN Doc. AV10 (1948), ant 25: Inernational ('ovenant on Economic, Siscial and Cultural Rights, GA Res. 2200A (XXI). UN IICHR (adopted 1966. ill force 1976), an 12. African [Banjul] Charter on Hiuman and Peoples Rights, OAU Doc. CAB/I.FG/67/3 rev 5. 21 I.1. M 5K (1982), an. 16: South Africa. Constitution of the Republic of South Africa 1996. No. I08 of 1996, s 27. For an overview of international human rights instruments relating to health, see Judith $A$ sher, the Righr ro Health: A Resource Mamual for NGOs (London: Commonwealth Medical Trust, 2004), online. Commonwealth Medical Trust <www.commat.org/Medical\%20Ethics\%20and\%20Right\%2010\%20) Health/Right $\% 2010 \% 20 \mathrm{Health} />$. 


\section{Canadian Interests}

The preceding analyses have largely addressed cross-border pharmacy from a transnational perspective. For Canada, however, the major issue (apart from co-signing) is the potential for firms to combat cross-border pharmacy by raising Canadian prices or restricting Canadian supplies. ${ }^{155}$ Thus far, firms have responded by trying to selectively limit supplies going to cross-border pharmacies, but there is concern that firms may step up pressure on Canadian price control policies or even discontinue sales to Canada entirely in order to preserve prices in the large U.S. market.

Firms have long opposed price controls (whether legislated or a function of national drug program buying power) in Canada and other exporting countries. ${ }^{136}$ Raising foreign, and in particular Canadian, prices to U.S. levels in order eliminate cross-border supply markets, however, would be difficult. The PMPRB appears well inoculated from legal challenges to the constitutionality of its price-setting powers. ${ }^{157}$ There is little room for negotiation under the current legislation since prices are set by reference to international or Ontario formulary prices, the latter themselves subject to absolute regulatory limits and cost-effectiveness evaluative mechanisms that resist price inflation. ${ }^{138}$ While cross-border pharmacy may magnify the effect of Canadian price controls on global firm profits, it is not clear what new opportunities for changes to Canadian price regulation are available to firms. It is also not clear, even if firms have sufficient leverage to extract a favourable response from the Canadian government to their concerns about cross-border pharmacy, that Canada would prefer to dismantle its price regulatory schemes rather than protect its own as well as firm interests by closing the border to drug exports.

An inability to constrain cross-border sales or eliminate the Canadian price differential could lead firms to greatly delay or even forego the release of new drugs in Canada in order to preserve higher prices in the much larger U.S. market. Though the gravity of such a "doomsday" scenario merits heightened caution, a number of factors weigh against its probability. The political and public backlash against firms would be severe, not only in Canada but also in the U.S., where consumers would be acutely aware of missed savings resulting from firms' decisions. On the legal front, sanctions under Canadian competition law could severely penalize firms that refuse to sell in Canada. Legalization of imports either

Health Canada, News Release, "Minister Dosanjh announces federal strategy to protect Canadians' supply of safe and affordable prescription drugs" (29 June 2005), online: <www.hc-sc.gc.ca/ahcasc/media/nr-cp/2005/2005_70_e.html>. See also Ed Lamb, "Canada moving to control bulk drug exports" (6 July 2005) Pharmacy Today, online: pharmacist.com <www.pharmacist.com/ articles/h_ts_0842.cfm>. Within the Canadian pharmacy community, therc have also been expressions of concern that cross-border pharmacy is reducing the availability of professional pharmacist services to Canadian patients. Sec e.g., Canadian Pharmacists Association, "Position Statement on Cross. Boarder Prescription Drug Trade" (February 2004), online: CPhA < www. pharmacists.ca/content/about - cpha/whats_happening/cpha_in_action/pdfCrossborderprescriptiondrugtrade.pdis.

14. Some commentators critical of the fact that other countries pay lower retail prices than the U.S. support lifling the U.S. re-importation ban for the very reason that it will force firms to "bargain harder" witl price-controlling countries and raise foreign prices to U.S. levels. See Roger Pilon, "The Reimportation Blues" The Wall Sireet Journal (1I October 2004) A18. 
through administrative certification of an import program or through new legislation would bring U.S. competition law into play as well; some proposed legislation explicitly forbids firms from refusing to supply Canadian pharmacies as a tactic for preventing re-imports. ${ }^{159}$

In a game of brinksmanship, Canada could even invoke "abuse of patent" provisions under s. 65 of the Patent Act: these authorize the issuance of compulsory licences or revocation of the patent when "the demand for the patented article in Canada is not being met to an adequate extent and on reasonable terms." 160 Though untested, s. 65 appears to be compliant with TRIPs, which permits member countries to impose compulsory licences as a remedy for patent abuse if licences are imposed on a case-by-case basis after negotiations with the patent holder have failed, licences are non-exclusive and limited in scope, adequate remuneration is paid, and there is opportunity for judicial reviews and the possibility of termination of the licence. $^{161}$

Moreover, Canada could source its drugs from suppliers in Europe and elsewhere. Crossborder pharmacies have already formed relationships with suppliers overseas to deal with firms' blacklisting of Canadian wholesalers. ${ }^{162}$ Indeed, the potential for greater international parallel trade in pharmaceuticals has important implications for firms. Success at raising Canadian prices to U.S. levels or closing the Canadian border to drug re-imports would not only require costly effort but could ultimately prove futile as other countries step in as lowcost suppliers. This scenario, in fact, is contemplated by the latent U.S. legislative framework and by proposed legislation which list a number of countries with advanced drug regulatory regimes and lower prices than the U.S., including European countries. ${ }^{163}$ Abandoning all nonU.S. markets that could re-export prescription drugs (primarily, the countries of Europe) is probably not feasible: lost profits would likely exceed the U.S. profit such an action would preserve.

While firms would like to see Canada increase prices, then, the more promising strategy will be to renew efforts to seal off the Canadian market from U.S. consumers. Firms can be expected to pressure the federal government to take an active role in suppressing exports. Firms might lobby the federal government to inspect cross-border pharmacies more aggressively and to seek out and report co-signing physicians and involved pharmacists to their relevant colleges. Firms could also seek the introduction of legislation restricting drug exports and/or a trade agreement to restrain re-exports comparable to agreements between the U.S. and Australia, Morocco and other nations.

For the past few years, cross-border pharmacy has produced significant financial gain for Canada. For cross-border pharmacy to continue to provide net benefit, though, the foreclosure of threats to Canada's prices and supply is critical. A full assessment of Canada's ability to protect itself through legal and political means from these threats requires a more thorough

Iw Smith, supra nole 86.

Hat Patent Act. supra note 18. 5. 65(2)(c). s. 66

"1.1 TRIPS, supra note 130, ant. 31.

"w.2 Leonard Zehr, "Net pharmacies think global in battle to keep supply flowing" The Globe and Mail (25 May 2004) Bl.

In. Proposed U.S. legislation allows imports not only from Canada but from six other countries. Illinois' plan allows imports from designated pharmacies in Canada and the U.K. Supra note 46. 
analysis of international trade agreements and competition and intellectual property law than has been presented here. At the very least, however, Canada would do well to leverage its position and aim for a meaningful "negotiated settlement" with firms over the cross-border pharmacy issue. If it closes the border to American patients, Canada cannot legitimately claim that it must do so because American patients need to be protected from Canadian drugs or because professional responsibility requires it, but only because its own interests are at stake. 